\title{
3-Hydroxyflavones and 3-Hydroxy-4-oxoquinolines as Carbon Monoxide-Releasing Molecules
}

\author{
Tatiana Soboleva and Lisa M. Berreau *(D) \\ Department of Chemistry \& Biochemistry, Utah State University, 0300 Old Main Hill, Logan, UT 84322-0300, \\ USA; tatiana.soboleva@aggiemail.usu.edu \\ * Correspondence: lisa.berreau@usu.edu; Tel.: +1-435-797-3509
}

Received: 3 March 2019; Accepted: 27 March 2019; Published: 30 March 2019

\begin{abstract}
Carbon monoxide-releasing molecules (CORMs) that enable the delivery of controlled amounts of $\mathrm{CO}$ are of strong current interest for applications in biological systems. In this review, we examine the various conditions under which $\mathrm{CO}$ is released from 3-hydroxyflavones and 3-hydroxy-4-oxoquinolines to advance the understanding of how these molecules, or derivatives thereof, may be developed as CORMs. Enzymatic pathways from quercetin dioxygenases and 3-hydroxy-4-oxoquinoline dioxygenases leading to $\mathrm{CO}$ release are examined, along with model systems for these enzymes. Base-catalyzed and non-redox-metal promoted $\mathrm{CO}$ release, as well as UV and visible light-driven CO release from 3-hydroxyflavones and 3-hydroxy-4-oxoquinolines, are summarized. The visible light-induced $\mathrm{CO}$ release reactivity of recently developed extended 3-hydroxyflavones and a 3-hydroxybenzo[ $g]$ quinolone, and their uses as intracellular CORMs, are discussed. Overall, this review provides insight into the chemical factors that affect the thermal and photochemical dioxygenase-type CO release reactions of these heterocyclic compounds.
\end{abstract}

Keywords: Gasotransmitter; mechanism; carbon monoxide; oxygen; heme oxygenase

\section{Introduction}

Advancing understanding of carbon monoxide $(\mathrm{CO})$ as a signaling molecule in humans, and evaluating its potential application as a therapeutic agent, are significant current goals in biomedical research [1,2]. Whether endogenously generated or introduced as $\mathrm{CO}$ gas, low concentrations of $\mathrm{CO}$ produce vasodilation, anti-inflammatory and anti-apoptotic effects that suggest it could be useful in treating cardiovascular disease [3-6]. The delivery of controlled amounts of $\mathrm{CO}$ to tumor tissue is also suggested as an approach for treating cancer [7,8]. Providing a precise amount of CO gas to a specific tissue or organ is difficult. Thus, to enhance the spatiotemporal control of $\mathrm{CO}$ release, carbon-monoxide releasing molecules (CORMs) have been developed. The vast majority of CORMs reported to date that have been used in in vitro and in vivo studies are metal carbonyl compounds, with the $\left[\mathrm{Ru}(\mathrm{CO})_{3} \mathrm{Cl}_{2}\right]_{2}$ dimer $(\mathrm{CORM}-2)$, and the water soluble molecules $\left[\mathrm{Ru}(\mathrm{CO})_{3} \mathrm{Cl}\right.$ (glycinato)] (CORM-3) and $\left[\mathrm{Mn}(\mathrm{CO})_{4}\left(\mathrm{~S}_{2} \mathrm{CNCH}_{3}\right)\left(\mathrm{CH}_{2} \mathrm{CO}_{2} \mathrm{H}\right)\right](\mathrm{CORM}-401)$, having been the most extensively employed $[9,10]$. Notably, the $\mathrm{Ru}(\mathrm{II})$ complexes exhibit complicated solution chemistry, including in blood plasma, and interact with proteins [11-16]. Thus, these compounds do not exhibit a single predictable formulation for $\mathrm{CO}$ delivery $[16,17]$. Complicating matters further is the fact that $\mathrm{CO}$ release from CORM-2, CORM-3 and CORM-401 occurs spontaneously via ligand exchange. This means that $\mathrm{CO}$ release begins when the compound is dissolved in a solution or buffer, and that there is no spatiotemporal control over CO delivery. Notably, recent studies also suggest that some biological effects that have been reported for the $\mathrm{Ru}$ (II)-containing CORMs and CORM-401 may not be due to CO release, but instead result from the reactivity of the metal complex or a fragment thereof $[18,19]$. 
These limitations provide the impetus for the development of new types of CO-releasing molecules that do not involve a metal carbonyl moiety.

Several research labs have taken up the challenge of preparing transition metal-free CORMs [20]. Examples reported to date include sodium boronocarbonate (CORM-A1 and analogs) [21] and norbornadiene-7-one derivatives [22], both of which are spontaneous CO-releasing CORMs (Figure 1(top)). Visible light-induced organic photoCORMs reported to date include unsaturated cyclic diketones [23], xanthene carboxylic acid [24], and meso-carboxy BODIPY [25] (Figure 1(bottom)). Limitations of these transition metal-free CORMs and photoCORMs include low yield multi-step synthetic procedures and a lack of well-defined CO release products. Thus, despite these advancements, further work is needed. The development of a tunable structural framework for CO release, that enables modulation of key properties (e.g., solubility, trackability in cells, cellular or subcellular targeting, triggered $\mathrm{CO}$ release) via standard synthetic and medicinal chemistry approaches would advance the field.

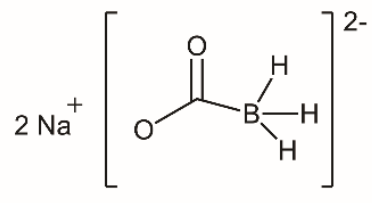<smiles>[R]c1ccc2c(c1)C(=O)C(=O)C21CCOC1</smiles>

$\mathrm{R}=\mathrm{H}$

$\mathrm{R}=-\left(\mathrm{OC}_{2} \mathrm{H}_{4}\right) \mathrm{OCH}_{3}$

$\mathrm{R}=-\mathrm{OC}_{8} \mathrm{H}_{17}$

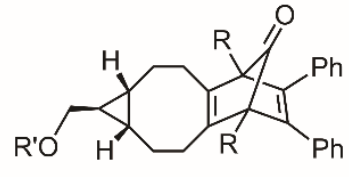

$\mathrm{R}=\mathrm{Ph}, \mathrm{R}^{\prime}=\mathrm{H}$

Figure 1. Examples of transition metal-free CO-releasing molecules (CORMs). Spontaneous (top) and visible light-induced (bottom) CORMs.

To design a new family of CORMs, we considered how $\mathrm{CO}$ is generated in biological systems. In humans, $\mathrm{CO}$ is endogenously generated with an equimolar amount of biliverdin in the first step of $\mathrm{O}_{2}$-dependent heme degradation in a reaction catalyzed by heme oxygenases (HO-1 and HO-2, Scheme 1(top)) [26,27]. The expression of HO-1 protein is a response to cellular stress, with the products of heme degradation exhibiting notable biological effects. Specifically, CO modulates vascular tone and biliverdin/bilirubin function as potent antioxidants [28]. In fungi and bacteria, the $\mathrm{O}_{2}$-dependent cleavage of 3-hydroxyflavone and 3-hydroxy-4-oxoquinoline derivatives occurs via enzyme-catalyzed dioxygenase-type reactions in which a 2,4-peroxo species undergoes $\mathrm{O}-\mathrm{O}$ and $\mathrm{C}-\mathrm{C}$ bond cleavage to give one equivalent each of $\mathrm{CO}$ and a carboxylic acid byproduct termed a depside (Scheme 1(bottom)) [29,30]. The biological implications of CO production in fungi and bacteria could be for its use as carbon, energy, or electron source [31]. Overall the similar nature of the heme oxygenase and bacterial/fungal $\mathrm{CO}$ release reactions suggests that if controlled $\mathrm{CO}$ release reactivity from 3-hydroxyflavone and 3-hydroxy-4-oxoquinoline derivatives can be harnessed, compounds of this class will provide a novel family of CORMs. An attractive feature of this strategy is that flavonols are already under significant investigation for their beneficial health effects. For example, quercetin, a 3-hydroxyflavone derivative found in many fruits and vegetables, is noted for its potentially beneficial anti-inflammatory, antioxidant and anti-cancer properties [32-34]. Triggered 3-hydroxyflavone or 3-hydroxy-4-oxoquinoline-based CORMs that could be targeted to specific locations for CO release would be especially attractive for probing the localized effects of $\mathrm{CO}$ delivery [35]. Using such bioactive frameworks, it may be possible to deliver $\mathrm{CO}$ while producing additional beneficial effects. 

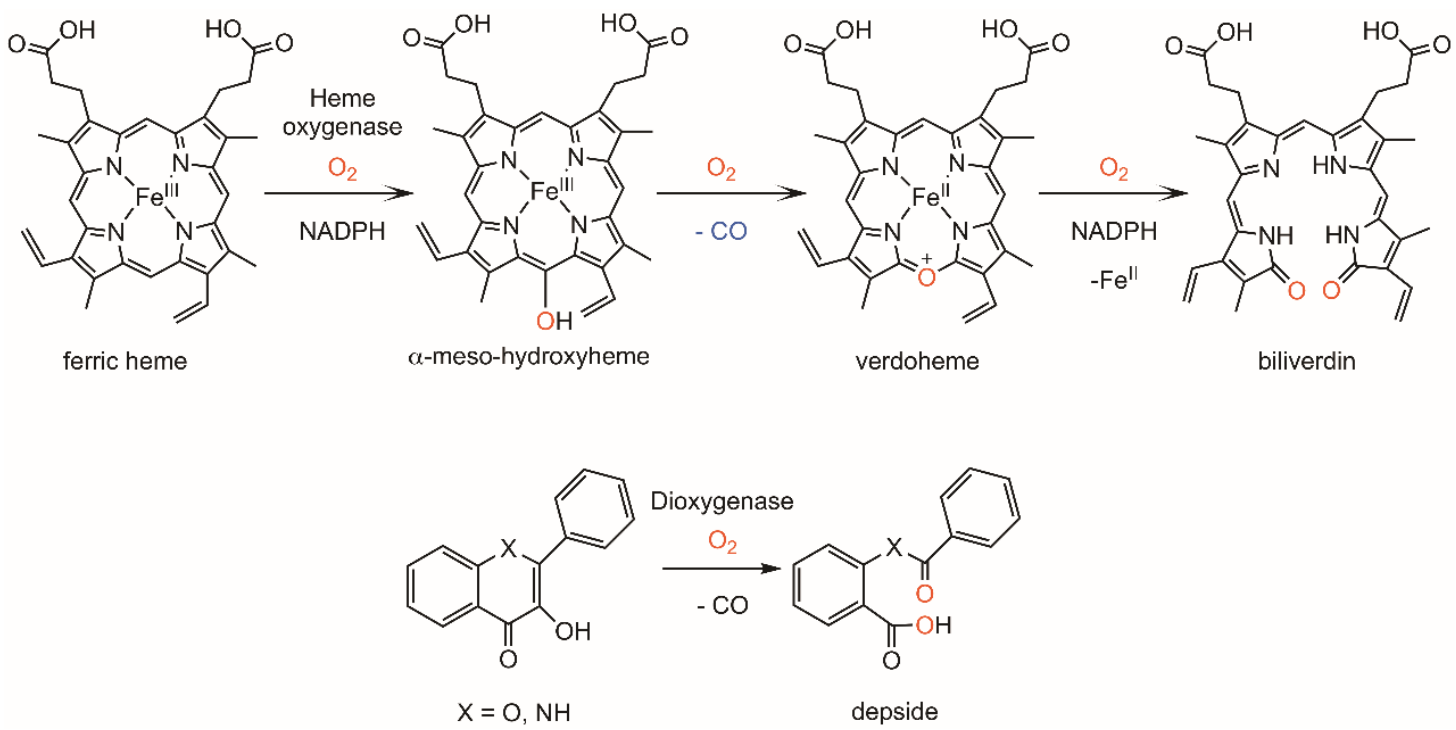

Scheme 1. CO release reactions catalyzed by heme oxygenases (top) and 3-hydroxyflavone and 3-hydroxy-4-oxoquinoline dioxygenases (bottom).

In this review we examine enzymatic and non-enzymatic reaction pathways leading to CO release from 3-hydroxyflavone and 3-hydroxy-4-oxoquinoline derivatives to elucidate conditions that influence $\mathrm{CO}$ release reactivity. Additionally, we discuss recent studies of photoinduced CO release from novel extended 3-hydroxyflavone and 3-hydroxybenzo[g]quinolone motifs. Overall, these combined results provide insight into the potential to control $\mathrm{CO}$ release from these heterocyclic frameworks and their potential for use as nature-inspired CORMs.

\section{CO Production from 3-Hydroxyflavones in Enzyme-Catalyzed Reactions and Model Systems}

\subsection{Fungal Flavonol Dioxygenases}

Soil microorganisms have divalent metal-containing enzymes that catalyze $\mathrm{CO}$ release from 3-hydroxyflavones. The flavonol dioxygenase from the fungus $A$. japonicus is a homodimer with a mononuclear $\mathrm{Cu}$ (II) center in the $\mathrm{N}$-terminal domain [36]. Two different active site coordination geometries were identified for the $\mathrm{Cu}$ (II) center. Approximately $70 \%$ of the mononuclear $\mathrm{Cu}$ (II) sites exhibit a distorted tetrahedral coordination environment comprised of three histidine donors and a water molecule. The remaining $\mathrm{Cu}$ (II) centers $(\sim 30 \%)$ have an additional glutamate ligand $\left(\mathrm{Glu}_{73}\right)$, resulting in an overall distorted trigonal bipyramidal geometry. EXAFS studies suggest that monodentate coordination of the substrate quercetin occurs with displacement of the water molecule [37]. As the enzyme exhibits 1000-fold lower activity in a site-directed mutant lacking $\mathrm{Glu}_{73}$, it has been suggested that this residue acts as an active site base for deprotonation of the flavonol 3-hydroxyl moiety [38]. The consensus reaction mechanism proposed for $\mathrm{CO}$ release involves the distorted square pyramidal five-coordinate $\mathrm{Cu}$ (II) enzyme/substrate complex forming a low-lying excited state $\mathrm{Cu}(\mathrm{I})$-flavonoxy radical species that can undergo reaction with ${ }^{3} \mathrm{O}_{2}$ either at the copper center or with the radical on the substrate (Scheme 2). Hybrid DFT calculations offer support for both pathways [39,40]. The number and location of hydroxyl substituents on the substrate determines the relative rate of enzymatic oxidation [41]. This relates both to the redox potential of the substrate and to secondary hydrogen bonding interactions that influence the positioning of the substrate in the active site [42]. 


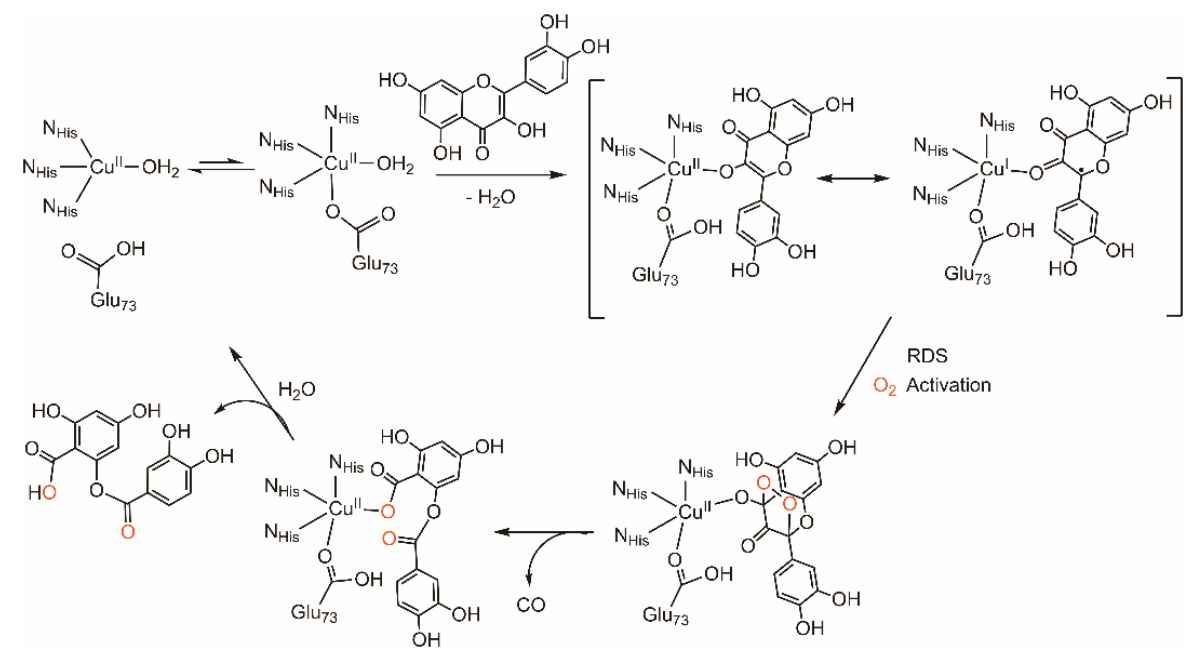

Scheme 2. Proposed reaction pathway for CO release catalyzed by fungal flavonol dioxygenases [39]. RDS indicates the rate-determining step.

\subsection{Bacterial Flavonol Dioxygenases}

Examples of flavonol dioxygenases from Bacillus subtilis [43-46] and Streptomyces sp. FLA [47-52] have been recently characterized. X-ray crystallographic studies of the iron-containing form of the Bacillus subtilis enzyme revealed a mononuclear five-coordinate Fe(II) center in each cupin domain of the bicupin protein [45]. Similar to the A. japonicus enzyme, the metal center is ligated by three histidine residues, a glutamate, and a water molecule. Initial kinetic studies of the $B$. subtilis enzyme as a function of metal ion provided an activity profile that has an approximate match to the Irving-Williams metal ion series for the stability of His- and Glu-ligated metal complexes [45]. Subsequent kinetic studies showed that inclusion of four different metal ions (Co(II), $\mathrm{Mn}(\mathrm{II}), \mathrm{Cu}(\mathrm{II})$, and $\mathrm{Ni}(\mathrm{II})$ ) produced higher levels of turnover than the Fe(II)-containing enzyme, with the highest turnover in the presence of $\mathrm{Mn}$ (II) [46]. The $k_{\text {cat }} / K_{\mathrm{M}}$ value and turnover number $\left(\sim 25 \mathrm{~s}^{-1}\right)$ for the $\mathrm{Mn}$ (II)-containing B. subtilis enzyme is similar to that reported for the $\mathrm{Cu}^{\mathrm{II}}$-containing $A$. japonicus enzyme. Both bind approximately two equivalents of metal ion, while the $\mathrm{Co}^{\mathrm{II}}$ and $\mathrm{Fe}^{\mathrm{II}}$-containing B. subtilis enzyme exhibit lower metal affinity as well as lower $k_{\text {cat }} / K_{M}$ values.

The quercetinase from Streptomyces sp. FLA is a monocupin protein that exhibits the highest turnover in the presence of $\mathrm{Ni}(\mathrm{II})$ and $\mathrm{Co}(\mathrm{II})$ [48]. Notably, anaerobic absorption spectra of the $\mathrm{Ni}$ (II) or Co(II)-containing Streptomyces sp. FLA enzyme in the presence of the quercetin substrate showed a hypsochromic shifts for the flavonol lowest energy absorption feature (Band I). The opposite is observed for the $\mathrm{Cu}(\mathrm{II})$-containing quercetinase of Aspergillus flavus wherein a bathochromic shift of the flavonol Band I is observed [49]. Considering redox potentials, the formation of transient $\mathrm{Co}(\mathrm{I})$ - or $\mathrm{Ni}(\mathrm{I})$-flavonoxy radical species is unlikely in the reaction pathway of the B. subtilis and Streptomyces sp. FLA quercetin dixoygenases (QDOs). This led to the proposal of the active site metal ion having a non-redox role and instead acting as a conduit for electron transfer from the metal-bound flavonol substrate to coordinated dioxygen $[46,48]$. Evidence for an active site metal structure relevant to this proposal was found in the X-ray crystallographic analysis of a cryotrapped version of the $\mathrm{Ni}(\mathrm{II})$-containing QDO from Streptomyces sp. FLA in the presence of $\mathrm{O}_{2}$ [50]. While exhibiting the typical coordination of three histidines and one glutamate to the $\mathrm{Ni}$ (II) center, a monodentate coordinated quercetin (via the $3-\mathrm{OH}$ which is likely deprotonated at the $\mathrm{pH}=8$ optimum for this enzyme) and a side-on coordinated $\mathrm{O}_{2}$ are also present (Figure 2). These species are proposed to represent flavonoxy and superoxide radicals, respectively, having formed via electron transfer from the flavonolato anion to $\mathrm{O}_{2}$ via the $\mathrm{Ni}(\mathrm{II})$ conduit. The $\mathrm{O}_{2}$ ligand is perpendicular to the $\mathrm{C} 2-\mathrm{C} 3$ and $\mathrm{C} 3-\mathrm{C} 4$ bonds, which subsequently undergo oxidative cleavage leading to $\mathrm{CO}$ release from the $\mathrm{C} 3-\mathrm{OH}$ moiety. Quantum mechanics/molecular mechanics (QM/MM) simulations from two different laboratories 
have provided insight into the possible reaction mechanism for the $\mathrm{Ni}(\mathrm{II})$-containing QDO [51,52]. Key differences between the two studies concern whether the active site glutamate $\left(\mathrm{Glu}_{74}\right)$ is protonated and the assignment of the rate-determining step. With regard to the former, Li, et al. performed their investigations with a protonated Glu 74 [51] whereas Wang, et al. investigated both protonation levels of $\mathrm{Glu}_{74}$ [52]. Both investigations suggest that dioxygen binding to the $\mathrm{Ni}$ (II) center results in electron transfer from the deprotonated flavonolato anion to $\mathrm{O}_{2}$ resulting in the formation of a $\mathrm{Ni}$ (II) flavonoxy radical/superoxide species with the $\mathrm{O}_{2}{ }^{-}$ligand coordinated in an end-on fashion. The ground state of this complex is an open-shell singlet with a high-spin $\mathrm{Ni}$ (II) center antiferromagnetically coupled to the superoxide and flavonoxy radicals. In the singlet state, the $\mathrm{O}_{2}$ moiety coordinates in an end-on fashion which differs from the observed side-on binding in the X-ray structure [50]. Attack of the terminal superoxide oxygen atom at $\mathrm{C} 2$ of the flavonoxy radical leads to the formation of a bridging $\mathrm{Ni}(\mathrm{II})$-peroxo species. Li, et al. suggest that a conformational change involving movement of the proximal $\mathrm{Ni}$ (II)-coordinated peroxo oxygen atom closer to the $\mathrm{C} 4$ atom of the flavonolato ligand is the rate-determining step, with a free energy barrier of $19.9 \mathrm{kcal} / \mathrm{mol}$ [51]. However, the calculations of Wang, et al. instead suggest that this step is not rate-determining and proceeds to two different intermediates that differ in terms of the orientation of the glutamate residue. In both calculations, subsequent formation of a five-membered cyclic intermediate via C4-O bond formation enables concurrent C2-C3 and C3-C4 bond cleavage, extrusion of CO, and formation of the depside product (Scheme 3). Wang, et al. propose that cleavage of the cyclic peroxide is rate-determining, with a free energy barrier of $17.4 \mathrm{kcal} / \mathrm{mol}$, which is similar to experimental kinetic data ( 15 kcal/mol) [48]. The calculations of Wang, et al. also indicate that if the glutamate residue is protonated, cleavage of the $\mathrm{C} 2-\mathrm{C} 3$ and $\mathrm{O}-\mathrm{O}$ bonds should occur leading to the formation of a $\alpha$-keto acid product, which has not been experimentally observed [52].

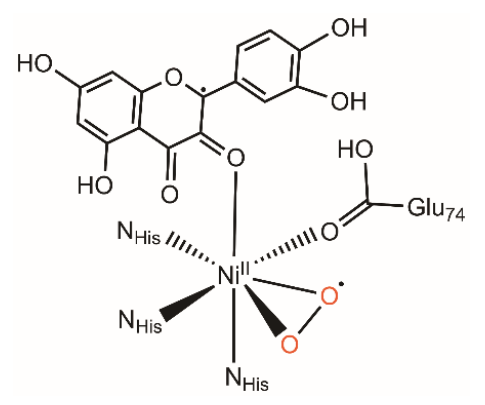

Figure 2. Representation of the active site features of cryotrapped Streptomyces sp. FLA in the presence of $\mathrm{O}_{2}$ [50].

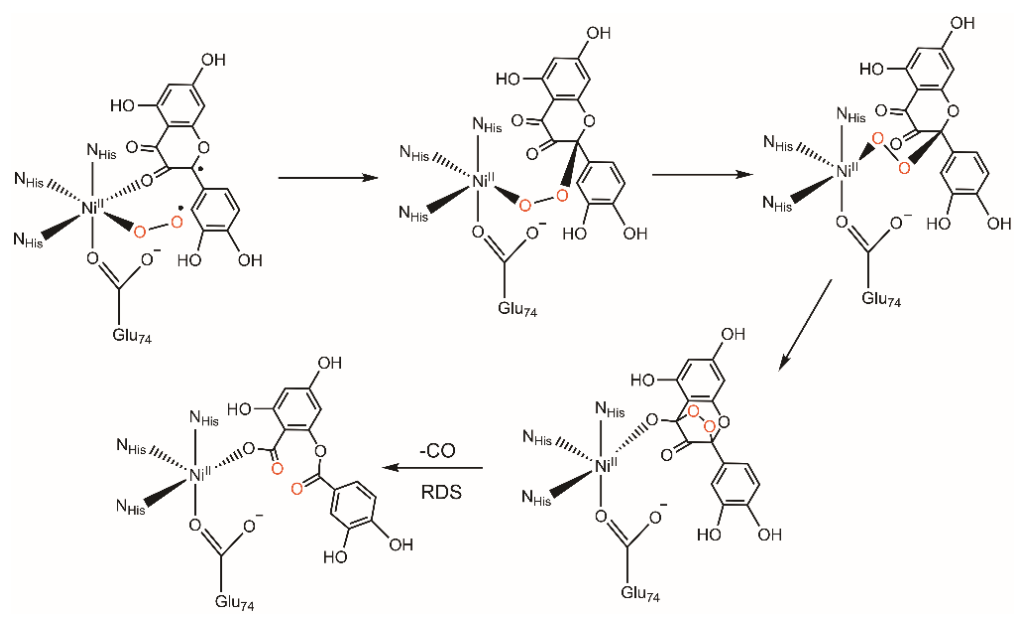

Scheme 3. Proposed reaction pathway for CO release from Ni(II)-containing QDO from Streptomyces sp. FLA [52]. RDS indicates the rate-determining step. 
As outlined above, bacterial quercetin dioxygenases (QDOs) catalyze the $\mathrm{O}_{2}$-dependent cleavage of flavonols to release $\mathrm{CO}$ and the corresponding depside. Recently, Farmer and co-workers have shown that the Mn-containing QDO from Bacillus subtilis will catalyze $\mathrm{CO}$ release from quercetin in the presence of a different small molecule, nitrosyl hydride (HNO) [53]. This nitroxygenase activity results in the incorporation of $\mathrm{N}$ and $\mathrm{O}$ atoms in the depside product (Scheme 4). The substitution of dioxygen with nitrosyl hydride is rationalized on the basis of the fact that the anionic form of nitrosyl exists as a triplet $\left({ }^{3} \mathrm{NO}^{-}\right)$and is isoelectronic with dioxygen [54]. The Mn-QDO nitroxygenase reactivity was found to be highly regioselective, producing only 2-((3,4-dihydroxyphenyl)(imino)methoxy)-4,6-dihydroxybenzoate (Scheme 4). Although dioxygenase activity is found for the $\mathrm{Fe}(\mathrm{II})$ - or $\mathrm{Co}(\mathrm{II})$-containing QDO enzymes, no nitroxygenase activity was found for these enzymes [53]. The nitroxygenase reaction pathway has been evaluated quantum chemically by Wojdyla and Borowski [55]. The lowest energy reaction sequence involves initial $\mathrm{Mn}$ (II)-O-NH complex formation. Addition of the NH moiety of the Mn(II)-nitroxyl to the flavonolato $\mathrm{C} 2$ center, followed by shifting of the hydrogen bond involving $\mathrm{Glu}_{69}$ from $\mathrm{O} 3$ to $\mathrm{O} 4$, enables $\mathrm{C} 4-\mathrm{O}$ bond formation (Scheme 4). The rate-determining step, with a barrier of $21.5 \mathrm{kcal} / \mathrm{mol}$, involves cleavage of the five-membered ring leading to $\mathrm{CO}$ extrusion. The regioselectivity of the reaction is an inherent property of the reactants. Specifically, the larger electrophilicity of the nitrogen atom in HNO makes the C2-N bond formation more feasible than C2-O, with the $\mathrm{C} 2-\mathrm{N}$ quercetin:HNO adduct being $>15 \mathrm{kcal} / \mathrm{mol}$ lower in energy versus the $\mathrm{C} 2-\mathrm{O}$ adduct.
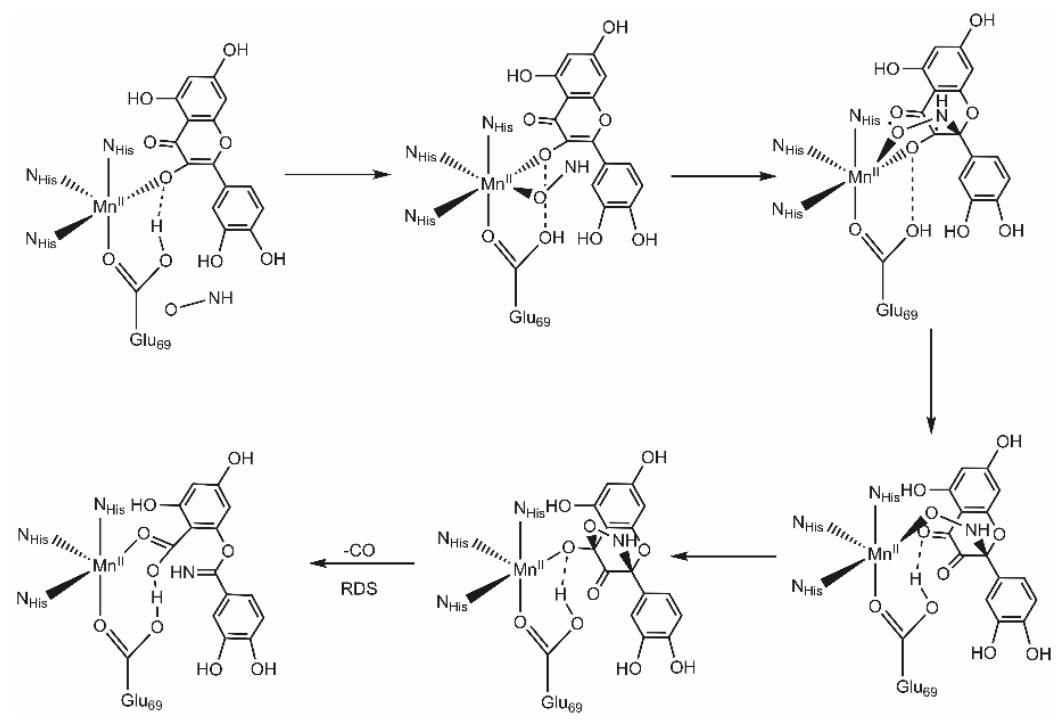

Scheme 4. Mechanism proposed for Mn(II)-containing bacterial QDO reactivity with HNO based on quantum chemical studies [55].

\subsection{Model Systems for Cu(II)-Containing Fungal QDOs}

Many synthetic model complexes have been reported for the enzyme/substrate adduct in fungal copper-containing quercetin dioxygenases, with many notable contributions from Speier and co-workers [56-58]. These $\mathrm{Cu}$ (II) complexes typically contain a supporting bidentate or tridentate nitrogen donor ligand to mimic histidine ligation and a bidentate-coordinated flavonolato ligand involving a five-membered chelate ring formed via coordination of the deprotonated $3-\mathrm{OH}$ moiety and the 4-keto oxygen atom. This flavonolato coordination mode is different from the monodentate coordination proposed in the enzyme/substrate complex of the A. japonicus enzyme, which is suggested to result from secondary interactions involving the quercetin substrate hydroxyl substituents [36,37]. The synthetic $\mathrm{Cu}(\mathrm{II})$ flavonolato complexes are much less reactive than the enzyme, typically undergoing $\mathrm{O}_{2}$-dependent dioxygenase-type reactivity only at elevated temperatures (e.g., $80-120^{\circ} \mathrm{C}$ ) in DMF. Enzyme-like products are generated, specifically 
O-benzoylsalicylate (depside) which is often retained on the $\mathrm{Cu}(\mathrm{II})$ center (Scheme 5), and $\mathrm{CO}$, which is typically not quantified. A bimolecular rate law for such reactions is $-\mathrm{d}[\mathrm{Cu}$ (II) flavonolato complex $] / \mathrm{dt}=k[\mathrm{Cu}$ (II) flavonolato complex $]\left[\mathrm{O}_{2}\right]$. An example of such a reaction is the $\mathrm{O}_{2}$-dependent $\mathrm{CO}$ release reaction of $\left[\mathrm{Cu}(\mathrm{idpa})(\mathrm{fla}) \mathrm{ClO}_{4}\right.$ (Scheme 5; fla = monoanion of 3-hydroxyflavone; idpa $=3,3^{\prime}$-imino-bis $(N, N$-dimethylpropylamine $)$ [59]. Similar to the proposed enzyme reaction pathway, an idpa-coordinated $\mathrm{Cu}(\mathrm{I})$-flavonoxy radical species is suggested to undergo single electron transfer from $\mathrm{Cu}(\mathrm{I})$ to $\mathrm{O}_{2}$ to form a $\mathrm{Cu}(\mathrm{II})$ superoxide adduct. The terminal oxygen atom of superoxide moiety subsequently combines with the flavonoxy radical to form a bridging peroxo species. Attack of the $\mathrm{Cu}$ (II)-coordinated peroxo oxygen atom at $\mathrm{C} 4$ results in the formation of a 2,4-cyclic peroxide species from which $C O$ extrusion and depside formation can occur. For this reaction, $\Delta H^{\ddagger}=64 \pm 5 \mathrm{~kJ} / \mathrm{mol}$ and $\Delta S^{\ddagger}=-120 \mathrm{~J} / \mathrm{mol} \cdot \mathrm{K}$. The negative entropy of activation is consistent with the $\mathrm{O}_{2}$ activation step to produce a $\mathrm{Cu}$ (II)-superoxo species being rate-determining. Enhanced electron density within the flavonolato ligand increases the oxygenation rate with the Hammett $\rho$ value being -0.29 .

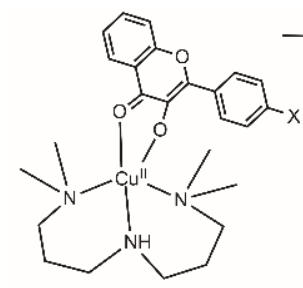

$\mathrm{X}=\mathrm{H},-\mathrm{CH}_{3},-\mathrm{Cl},-\mathrm{OCH}_{3}$

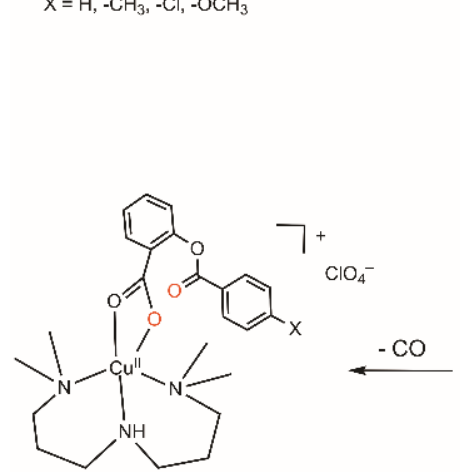

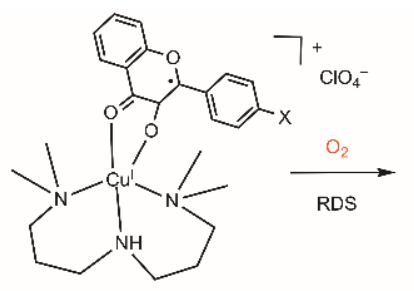

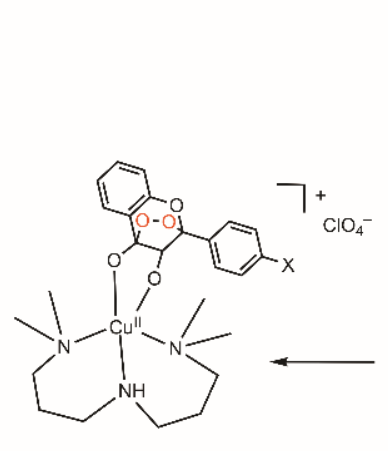

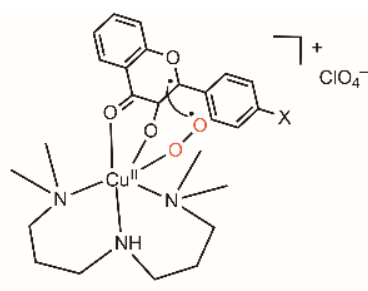

$\downarrow$

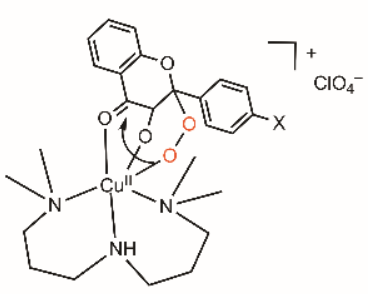

Scheme 5. Reactivity of $[\mathrm{Cu}(\mathrm{idpa})(\mathrm{fla})] \mathrm{ClO}_{4}$ derivatives with $\mathrm{O}_{2}$ to release $\mathrm{CO}$ [59].

Notably, addition of an exogenous carboxylate donor ligand (acetate or triphenylacetate) to solutions of $[\mathrm{Cu}(\mathrm{idpa})(\mathrm{fla})] \mathrm{ClO}_{4}$ results in an acceleration of the $\mathrm{CO}$ release reaction $[57,60]$. This is attributed to $\mathrm{Cu}$ (II) coordination of the carboxylate ligand, which results in a shift to monodentate coordination of the flavonolato ligand (Scheme 6). The enhanced electron density within the flavonolato moiety at $\mathrm{C} 2$ makes direct electron transfer to $\mathrm{O}_{2}$ more viable thus enhancing the rate of formation of $\mathrm{O}_{2}{ }^{-}$, which was detected in reaction mixtures.
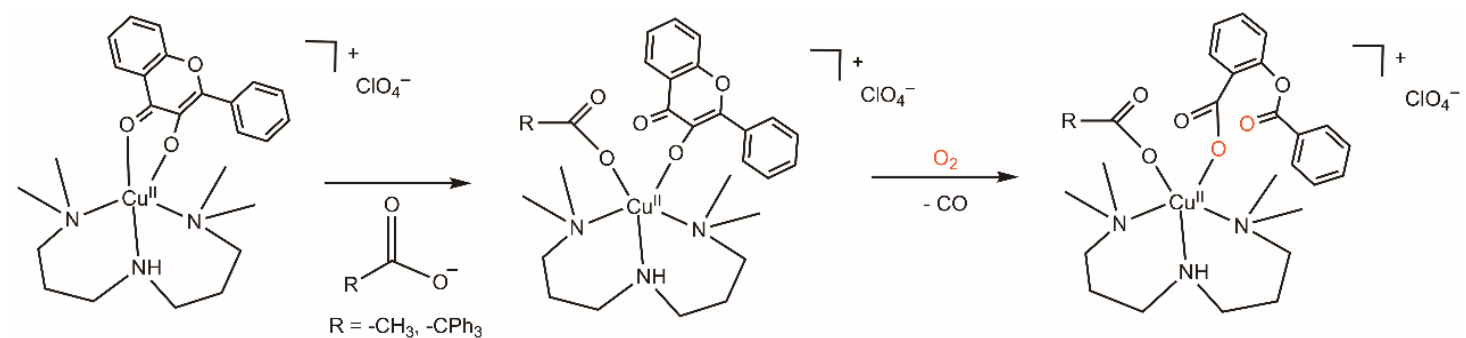

Scheme 6. Effect of carboxylate addition on flavonolato coordination [60]. 
Some $\mathrm{Cu}$ (II) flavonolato complexes, such as $\left.[\mathrm{Cu} \text { (phen)(fla })_{2}\right]$ and $\left[\mathrm{Cu}(\mathrm{bpy})(\mathrm{fla})_{2}\right]$, do not exhibit CO release but instead undergo reaction via a 1,2-dioxetane intermediate to give 2-hydroxyphenylglyoxylate following hydrolysis (Scheme 7) [61,62]. The ligand environment and Lewis acidity of the $\mathrm{Cu}$ (II) center are suggested to affect the regioselectivity of carbon-carbon bond cleavage by influencing the electrophilicity of the flavonolato carbonyl center [61]. Evidence for the involvement of a 1,2-dioxetane are emission bands at 506, 546, and $578 \mathrm{~nm}$ [62].
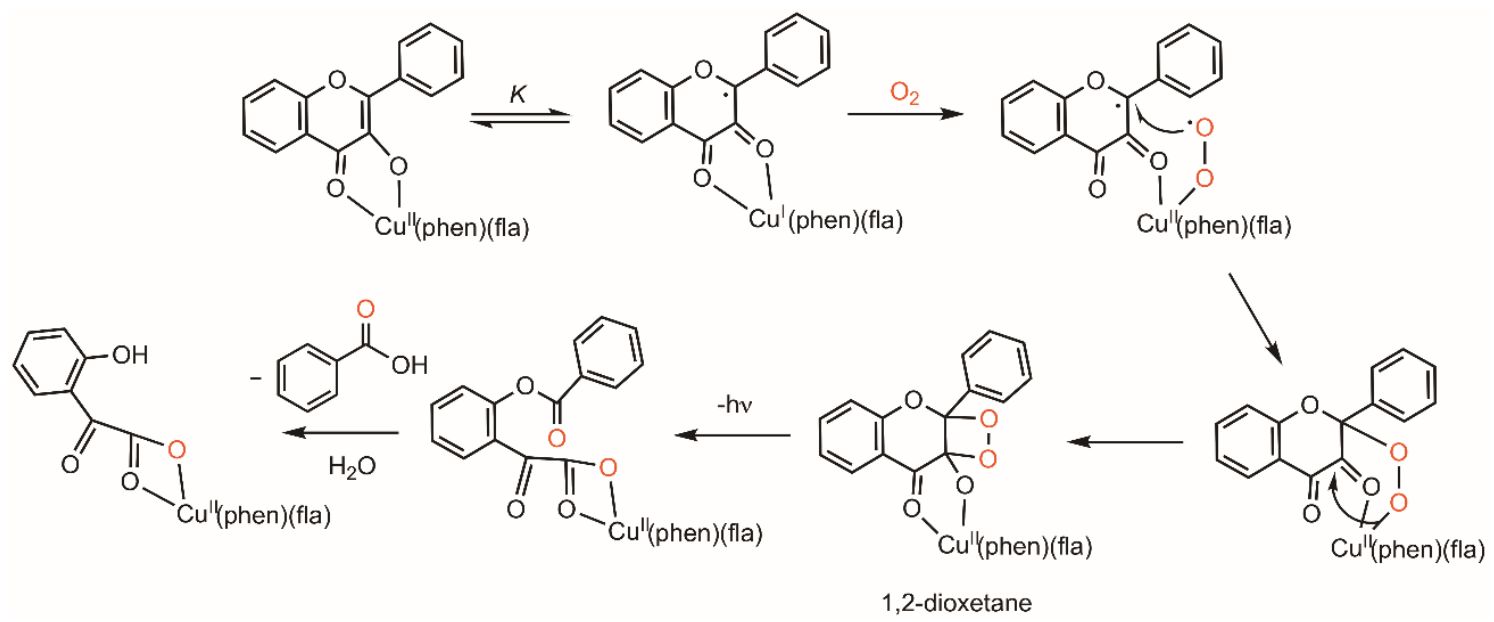

Scheme 7. $\mathrm{O}_{2}$ reactivity of a phenanthroline-coordinated $\mathrm{Cu}(\mathrm{II})$ flavonolato complex that does not result in CO release [61].

\subsection{Model Systems for Bacterial QDOs}

Grubel, et al. synthesized the first series of divalent $3 d$ metal flavonolato compexes of structural relevance to bacterial quercetin dioxygenases [63]. These complexes, supported by an aryl-appended tris(pyridylmethyl)amine ligand, have thus far not been investigated for thermal CO release reactivity. Sun, et al. and Matuz, et al. subsequently prepared, characterized, and examined the $\mathrm{O}_{2}$-dependent $\mathrm{CO}$ release reactivity of two series of divalent metal ion flavonolato complexes (Scheme 8) [64,65]. Sun, et al. studied complexes supported by a carboxylate-containing $\mathrm{N}_{3} \mathrm{O}$-donor ligand (Scheme 8a) [64]. A metal ion dependence on the second-order rate constant for oxidative cleavage $(\mathrm{Fe}(\mathrm{II})>\mathrm{Cu}$ (II) $>\mathrm{Co}$ (II) $>$ $\mathrm{Ni}(\mathrm{II})>\mathrm{Zn}(\mathrm{II})>\mathrm{Mn}(\mathrm{II})$ ) correlates with the oxidation potential of the coordinated flavonolato ligand, which in turn is influenced by the Lewis acidity of the metal center. These oxidative cleavage reactions occurred at lower temperatures than those reported for synthetic complexes having a neutral nitrogen supporting ligand environment [65], likely due to the reduced Lewis acidity of the metal center. The yield of $\mathrm{CO}$ produced using the $\mathrm{Fe}$ (II) complexes supported by carboxylate-containing $\mathrm{N}_{3} \mathrm{O}$-donor ligand was determined to be $68 \%$. The series of complexes reported by Matuz, et al. (Scheme $8 \mathrm{~b}, \mathrm{c}$ exhibit similar reactivity in terms of the products generated [65]. The ester-appended derivatives shown in Scheme $8 c$ are more reactive that the propionate analogs (Scheme $8 b$ ), suggesting that ligand exchange involving the monodentate anion is important in the rate-determining $\mathrm{O}_{2}$ activation step. 
a)

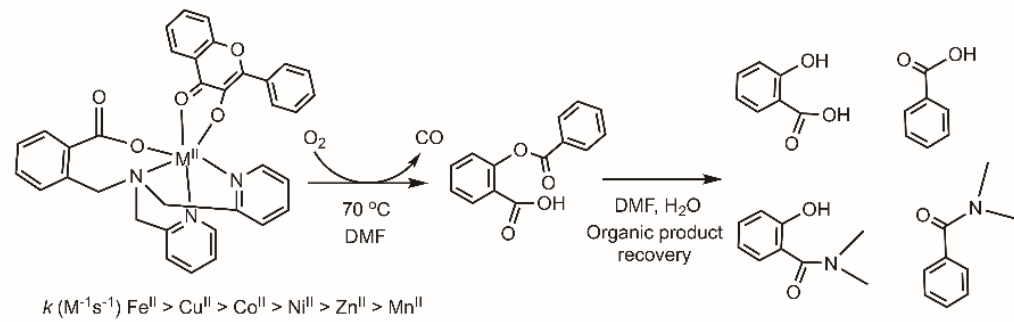

b)
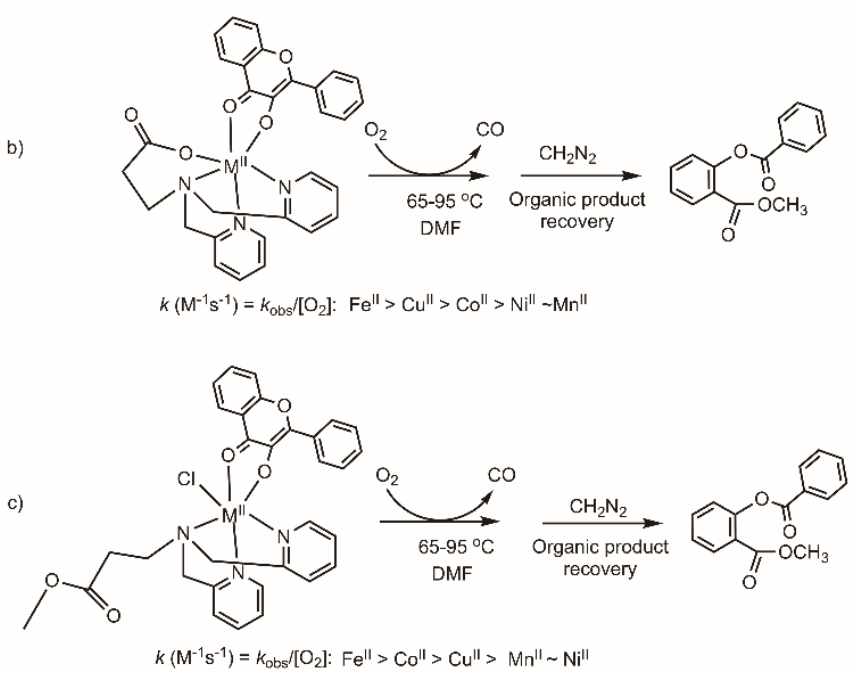

Scheme 8. Dioxygenase-type reactivity of divalent metal complexes containing a carboxylate or ester appendage $[64,65]$.

Enhancing the electron density within the carboxylate moiety of the supporting chelate ligand produces structural, electronic and reactivity effects via the benzoate-M(II)-O(4)=C(27)-C(21)=C(22) conduit in $\mathrm{M}(\mathrm{II})$-containing flavonolato complexes. Specifically, incorporation of an electron donating group on the ligand benzoate moiety produces a smaller torsion angle between the flavonol B and C rings (Scheme 9), a $\pi \rightarrow \pi^{*}$ absorption band that is shifted to lower energy, and a lower redox potential for the flavonolato moiety. These characteristics result in higher dioxygenase reactivity in $\mathrm{Co}$ (II), $\mathrm{Ni}$ (II) and Fe(II) complexes [66-68]. CO quantification studies were not reported for these reactions.

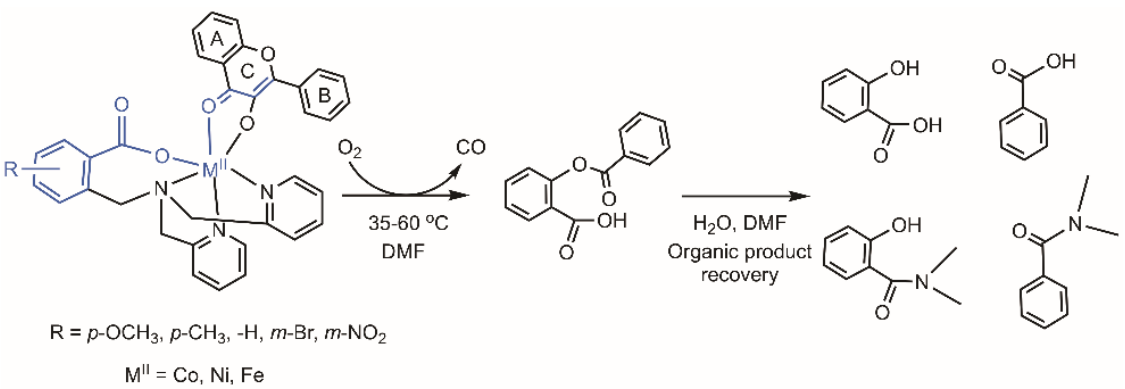

Scheme 9. Electronic effects on flavonolato ligand reactivity with $\mathrm{O}_{2}$. The blue highlighted portion of the structure shows the benzoate-M(II)-O(4)=C(27)-C(21)=C(22) conduit [66-68].

\subsection{CO-Release Reactivity of Other Metal Flavonolato Complexes}

Simple metal flavonolato complexes that lack structural relevance to quercetin dioxygenase but exhibit $\mathrm{CO}$ release reactivity have also been reported by Speier and co-workers [56,69-71]. When heated in DMF at $95{ }^{\circ} \mathrm{C}$, bis- and tris-flavonolato complexes such as $\mathrm{Mn}(\mathrm{fla})_{2}(\mathrm{py})_{2}$ and $\mathrm{Fe}\left(4^{\prime}-\mathrm{MeO}-\mathrm{fla}\right)_{3}$ (Figure 3) release $\mathrm{CO}$ in near quantitative yields $(80-90 \%)$ resulting in the formation of the corresponding $\mathrm{O}$-benzosalicylate complexes. The rate law for these reactions is 
$-\mathrm{d}[$ complex $] / \mathrm{d} t=k[$ complex $]\left[\mathrm{O}_{2}\right]$, with the rate constant for the $\mathrm{Mn}$ (II) derivative being approximately 6-fold larger than that of the Fe(II) complex (0.50 and $0.08 \mathrm{M}^{-1} \cdot \mathrm{s}^{-1}$, respectively) at $100^{\circ} \mathrm{C}$ in DMF.
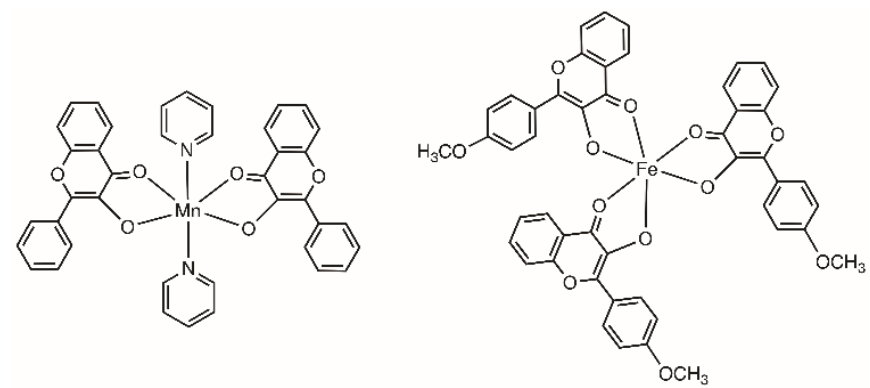

Figure 3. Mononuclear Mn(II) and Fe(III) flavonolato complexes that undergo CO release in DMF [69].

Anion effects on the $\mathrm{O}_{2}$ reactivity of $\mathrm{Fe}(\mathrm{III})$ flavonolato complexes have been reported [72]. The Fe(III) flavonolato complex Fe(fla)(salen) (fla = anion of 3-hydroxyflavone, Scheme 10) undergoes reaction with $\mathrm{O}_{2}$ at $100-125^{\circ} \mathrm{C}$ in DMF to give an $O$-benzosalicylate complex and $\mathrm{CO}$ [72]. The rate law for this reaction is $-\mathrm{d}\left[\mathrm{Fe}(\right.$ fla)(salen) $] / \mathrm{d} t=k\left[\mathrm{Fe}(\right.$ fla)(salen) $]\left[\mathrm{O}_{2}\right]$ with $k=2.07 \pm 0.12 \mathrm{M}^{-1} \cdot \mathrm{s}^{-1}$, $\Delta H^{\ddagger}=76 \mathrm{~kJ} / \mathrm{mol}$ and $\Delta S^{\ddagger}=-94 \mathrm{~J} / \mathrm{mol} \cdot \mathrm{K}$ at $373.16 \mathrm{~K}$. Incorporation of an electron-donating group at the para position of the flavonol results in a 2.5 -fold increase in the rate of reaction. A significant 171-fold rate enhancement is produced upon addition of a bulky carboxylate anion (triphenyl acetate, $\mathrm{Ph}_{3} \mathrm{CCOO}^{-}$, Scheme 10). The coordination of this anion to the Fe(III) center is proposed to induce a shift in the flavonolato coordination mode from bidentate to monodentate. The enhanced electron density within the flavonolato ligand is suggested to be responsible for the dramatic rate enhancement. The overall rate law for the anion-containing reaction is Rate $=k[\mathrm{Fe}(\mathrm{fla})($ salen $)]\left[\mathrm{O}_{2}\right]\left[\mathrm{Ph}_{3} \mathrm{CCOO}^{-}\right]$with $\Delta H^{\ddagger}=35 \mathrm{~kJ} / \mathrm{mol}$ and $\Delta S^{\ddagger}=-120 \mathrm{~J} / \mathrm{mol} \cdot \mathrm{K}$ at $313.16 \mathrm{~K}$. This lower activation barrier results in a dioxygenase-type $\mathrm{CO}$ release reaction that can proceed at room temperature.
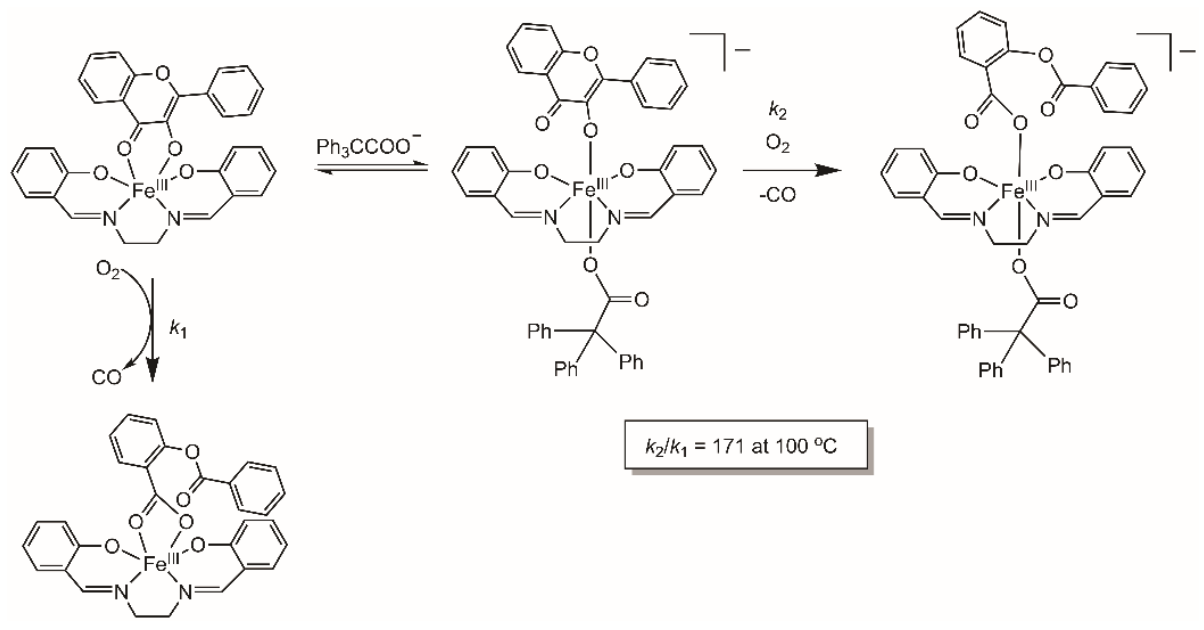

$k_{2} / k_{1}=171$ at $100^{\circ} \mathrm{C}$

Scheme 10. Effect of bulky carboxylate ligation on the dioxygenase-type CO release reactivity of an $\mathrm{Fe}(\mathrm{III})$ flavonolato complex [72].

\subsection{Summary}

Studies of quercetin dioxygenases and model systems for these enzymes have provided insight into the factors that influence the reactivity of metal-flavonolato species with $\mathrm{O}_{2}$ in dioxygenase-type CO-releasing reactions. In model complexes containing a flavonolato ligand coordinated in a bidentate manner via a five-membered chelate ring, high temperatures are typically required to induce $\mathrm{O}_{2}$-dependent $\mathrm{CO}$ release reactivity. Key to increasing this reactivity is to enhance the electron density within the flavonolato moiety, as this lowers the activation barrier for electron transfer for $\mathrm{O}_{2}$. 
Enhanced electron density can be achieved by adding electron-donating substituents on the flavonolato ligand, increasing the electronic donor properties of a supporting chelate ligand, or by introducing additional bulky anionic donors that via coordination to the metal center induce a shift to monodentate metal-flavonolato coordination. To date, the systems that exhibit reactivity closest to room temperature involve monodentate flavonolato coordination similar to that proposed in the enzymatic reaction pathways. In organic solvents, few of these complexes have been evaluated in terms of quantification of the amount of $\mathrm{CO}$ released. Additionally, $3 d$ metal flavonolato complexes have not been evaluated as CO-releasing molecules in aqueous environments. Under such conditions, ligand exchange with water would likely influence the $\mathrm{CO}$ release reactivity.

\section{CO Production from 3-Hydroxy-4-oxoquinolines via Cofactor-Free Enzyme-Catalyzed Reactions and in Metal-Containing Synthetic Systems}

\subsection{Enzyme-Catalyzed Reactions}

The cofactor-free bacterial 1H-3-hydroxy-4-oxoquinaldine 2,4-dioxygenase (Hod) from Arthrobacter ilicis Rü61a and 1H-3-hydroxy-4-oxoquinoline 2,4-dioxygenase (Qdo) from Pseudomonas putida 33/1 catalyze the insertion of dioxygen at $\mathrm{C} 2$ and $\mathrm{C} 4$ of the 3-hydroxy-4-oxoquinoline substrates resulting in the release in $\mathrm{CO}$ (Scheme 11(top)) [73-77]. In terms of sequence, these enzymes are rare examples of dioxygenases that belong to the $\alpha / \beta$ hydrolase family. Hod and Qdo do not contain a cofactor or metal ion but have a catalytically required histidine residue ( $\mathrm{His}_{251}$ in Hod; $\mathrm{His}_{244}$ in Qdo). The enzyme-bound monoanion of $1 \mathrm{H}$-3-hydroxy-4-oxoquinaldine is proposed to undergo single electron transfer to $\mathrm{O}_{2}$ in the rate-determining step to produce a triplet superoxide complex $\left({ }^{3} \mathrm{I}_{1}\right.$, Scheme 11(bottom)). An internal electron transfer leads to a closed-shell singlet $\left({ }^{1} \mathrm{I}_{1}\right)$. Attack of the peroxide terminal oxygen at $\mathrm{C} 4$ followed by formation of a peroxide bridge between $\mathrm{C} 2$ and $\mathrm{C} 4$ leads to the cyclic species from which $\mathrm{CO}$ extrusion can occur to give $\mathrm{N}$-acetylanthranilate anion. This reaction pathway is consistent with ${ }^{18} \mathrm{O}_{2}$ labeling studies, which showed that the catalytic reaction of Hod results in incorporation of two labeled oxygen atoms. It should be noted that the substrates for Hod and Qdo exhibit similar reactivity under basic, aerobic conditions (vide infra). The role of the enzyme in these systems may be to provide a low-dielectric reaction environment that is optimal for positioning the substrate and for electron transfer to $\mathrm{O}_{2}$ and $\mathrm{C}-\mathrm{O}$ bond formation.
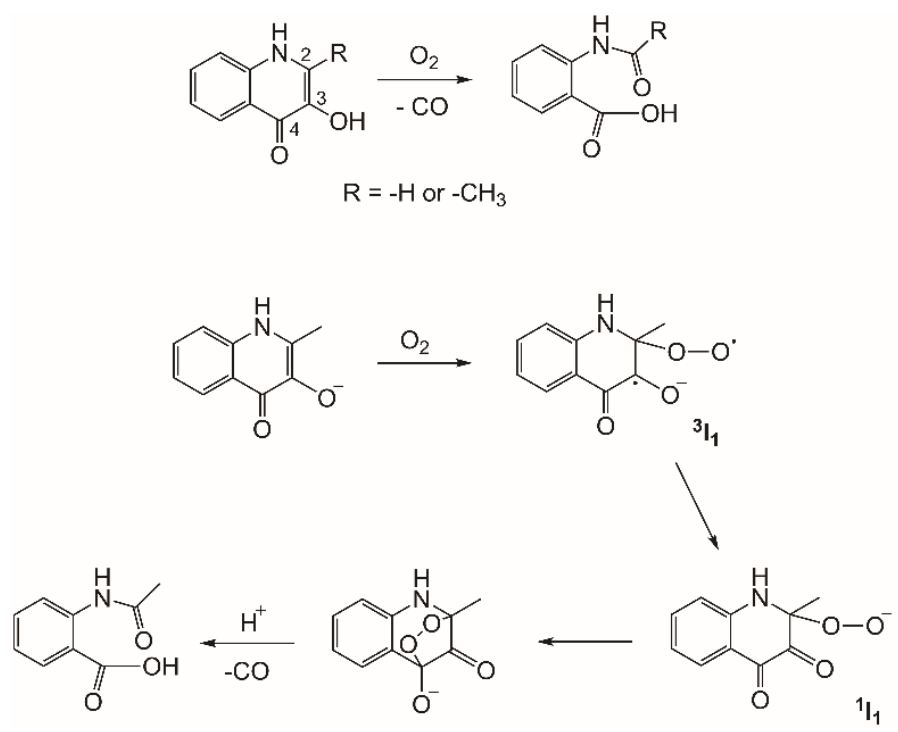

Scheme 11. (top) Reaction catalyzed by $1 \mathrm{H}$-3-hydroxy-4-oxoquinaldine 2,4-dioxygenase $\left(\mathrm{R}=-\mathrm{CH}_{3}\right.$; Hod) and 1H-3-hydroxy-4-oxoquinoline 2,4-dioxygenase ( $\mathrm{R}=-\mathrm{H}$; Qdo). (bottom) Proposed reaction pathway of Hod based on kinetic, computational and spectroscopic studies. 


\subsection{Synthetic Systems}

While not structurally relevant to the active site chemistry of Hod, copper complexes containing a 1H-2-phenyl-3-hydroxy-4-oxoquinolinate ligand have been shown to undergo $\mathrm{O}_{2}$-dependent $\mathrm{CO}$ release [78]. As shown in Scheme 12, similar to the reactivity of $\mathrm{Cu}$ (II) flavonolato complexes, these complexes undergo stoichiometric $\mathrm{CO}$ release from each 3-hydroxy-4-oxoquinoline ligand upon heating in DMF.

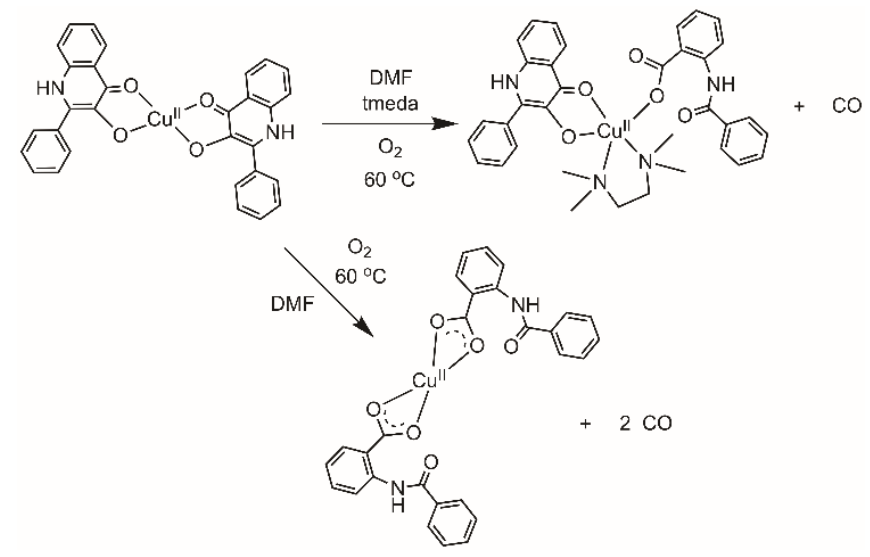

Scheme 12. Reactions of a Cu(II) bis $1 H$-2-phenyl-3-hydroxy-4-oxoquinolinate complex with $\mathrm{O}_{2}$ to release $\mathrm{CO}[78]$.

A non-heme iron catalyst has been reported by Speier, et al. to mediate the $\mathrm{O}_{2}$-dependent cleavage of 3-hydroxyflavone and 1- $\mathrm{H}$-2-phenyl-3-hydroxy-4-oxoquinoline to produce $\mathrm{CO}$ [79]. At $100{ }^{\circ} \mathrm{C}$ in DMF and with a ratio of 1:25 between the complex, [Fe(III)(O-bs)(salen)] (Scheme 13), and the substrate, catalytic dioxygenation occurs to give the products, $\mathrm{O}$-benzoylsalicylic acid and $\mathrm{N}$-benzoylanthranilic acid in $78 \%$ and $64 \%$ yield, respectively, with concomitant release of $\mathrm{CO}$. Initial rate studies showed that 3-hydroxyflavone is three-times more reactive than 2-phenyl-3-hydroxy-4 $(1 \mathrm{H})$-quinoline toward $\mathrm{O}_{2}$. As expected, increasing the basicity of the flavonol increases the rate of the $\mathrm{O}_{2}$ reaction. These reactions proceed by single electron transfer (SET) wherein the metal-coordinated deprotonated substrate provides an electron for the reduction of $\mathrm{O}_{2}$. Superoxide formation was detected using nitroblue tetrazolium (NBT) as a scavenger to produce formazan. Proceeding through the reaction pathway as shown in Scheme 13, an endoperoxide intermediate is formed that undergoes C-C and $\mathrm{O}-\mathrm{O}$ bond cleavage to release $\mathrm{CO}$ and generate an enzyme-type organic byproduct. The formation of $\mathrm{O}$-benzoylsalicylate or $\mathrm{N}$-anthranilate as products enhances the rate of reaction through coordination to the $\mathrm{Fe}(\mathrm{III})$ center as previously described.

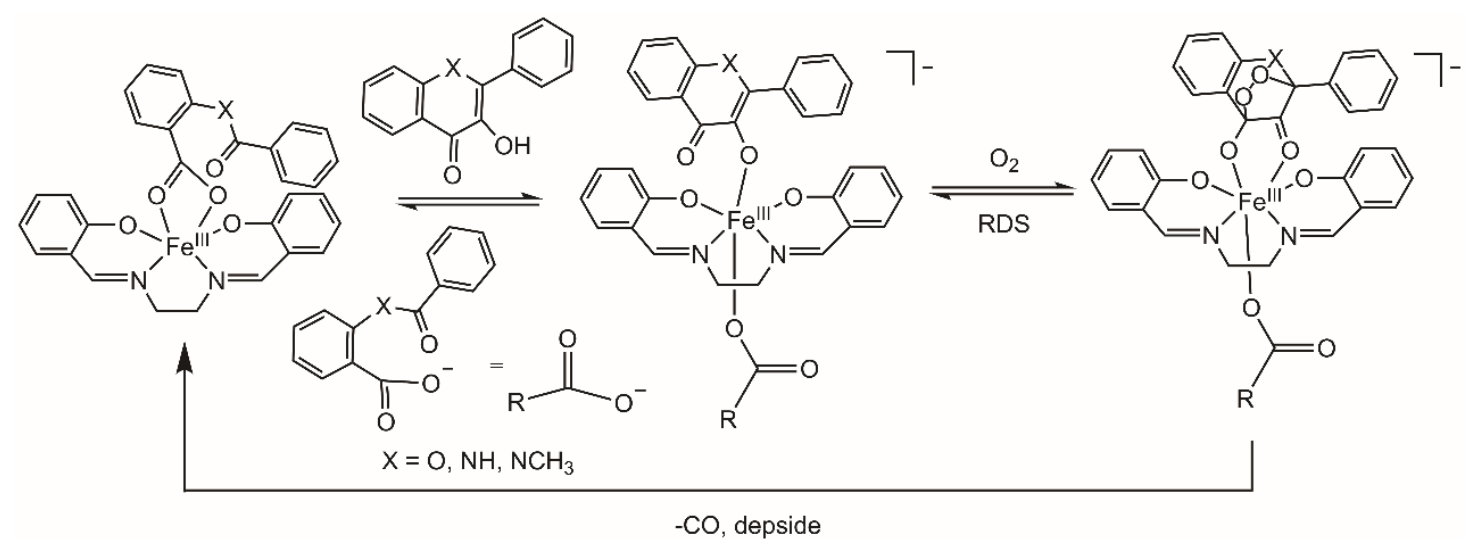

Scheme 13. Oxygenation of 3-hydroxyflavone and 3-hydroxy-4-oxoquinoline derivatives with the release of $\mathrm{CO}$ catalyzed by [Fe(III)(O-bs)(salen)] [79]. 


\subsection{Summary}

Overall these combined studies indicate that 3-hydroxy-4-oxoquinoline derivatives undergo enzyme-catalyzed or metal-promoted reactions to release $\mathrm{N}$-benzoylanthranilic acid and an equivalent of $\mathrm{CO}$. This clean reactivity suggests that 3-hydroxy-4-oxoquinolines may also be useful as a CO-releasing motif. Notably, the slower rate of $\mathrm{CO}$ release of 2-phenyl-3-hydroxy-4(1H)-quinoline derivatives versus 3-hydroxyflavones upon reaction with $\mathrm{O}_{2}$ indicates that the heteroatom within the pyrone ring is a key factor in determining the rate of $\mathrm{CO}$ release.

\section{CO Production from 3-Hydroxyflavones and 3-Hydroxy-4-oxoquinolines via Base-Catalyzed and Non-Redox Metal Assisted Reactions}

\subsection{3-Hydroxyflavones}

Speier, et al. have previously summarized base-catalyzed flavonol oxygenation that results in $\mathrm{CO}$ release in protic solvents as well as non-redox metal-assisted $\mathrm{CO}$ release reactions in a variety of solvents [56,80-82]. Briefly, flavonol oxygenation under these conditions $\left(40-90{ }^{\circ} \mathrm{C}\right)$ proceeds via one of two mechanistic pathways: single electron transfer (SET) (Scheme 14(Path a)) or a one-step electrophilic reaction of triplet oxygen with the flavonolate ion (Scheme 14(Path b)). The former was found to occur in aprotic solvents via SET from the flavonolate ion to triplet $\mathrm{O}_{2}$, yielding a flavonoxy radical and superoxide ion, which subsequently undergo fast radical-radical coupling to give a 2-hydroxyperoxyflavan-3,4-dionate intermediate. The resulting species then undergoes an intramolecular nucleophilic attack at $\mathrm{C} 4$ leading to the formation of an unstable endoperoxide that decomposes into depside (O-benzoylsalicylate) and $\mathrm{CO}$ [81]. In the case of the electrophilic reaction between oxygen and the flavonolato ion, a detailed mechanistic study was carried out with $4^{\prime}$-substituted flavonol derivatives in $50 \%$ DMSO- $\mathrm{H}_{2} \mathrm{O}$ in the $\mathrm{pH}$ range 6.4-10.8 to map out the reaction pathway [82]. This reaction showed specific base catalysis. A linear Hammett plot yielded a negative reaction constant $(\rho=-0.50)$ implying that a higher electron density on the flavonolate ion makes it more nucleophilic thus facilitating electrophilic attack by $\mathrm{O}_{2}$. Both oxygenation pathways yield stoichiometric formation of $\mathrm{CO}$ and depside and/or its hydrolysis byproducts (salicylic acid and benzoic acid).

Farmer, et al. have reported the base-catalyzed reaction of $\mathrm{HNO}$ with quercetin [83]. Above $\mathrm{pH} 7$, this reaction occurs to give 3,4-dihydroxybenzonitrile, a cleavage product indicating that the regioselectivity observed in the reaction catalyzed by the Mn-containing QDO from Bacillus subtilis (Scheme 4) is maintained in the base-catalyzed reaction. Kinetic and thermodynamic studies by Kumar and Farmer have provided evidence that the base-catalyzed reaction between $\mathrm{HNO}$ and quercetin occurs via single electron transfer (SET) [83]. It is notable that this reaction occurs orders of magnitude faster than the corresponding dioxygenation. This has been attributed to the difference in driving force for SET in the rate-determining step.

\subsection{3-Hydroxy-4-oxoquinolines}

For 3-hydroxy-4-oxoquinoline derivatives, a mixture of products resulting from endoperoxide or 1,2-dioxetane species forms, with the ratio depending on the solvent. $\mathrm{CO}$ release only occurs via the reaction involving the endoperoxide, with the 1,2-dioxetane undergoing $\mathrm{C}-\mathrm{C}$ bond cleavage to give a phenylglyoxalic acid derivative (Scheme 14). A long-lived radical is observed in the reaction of 1- $\mathrm{H}$-2-phenyl-3-hydroxy-4-oxoquinoline with $\mathrm{O}_{2}$ providing evidence for a single electron transfer pathway in the oxygen activation step [84]. 


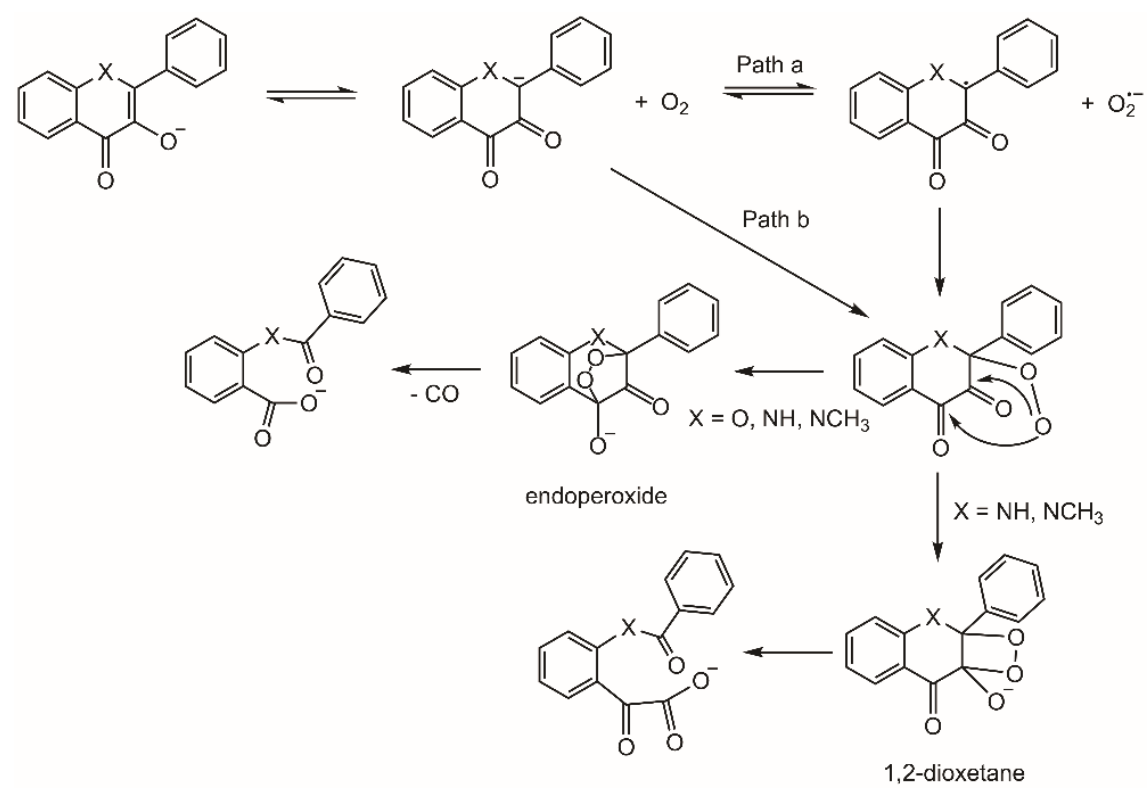

Scheme 14. Reaction pathways leading to CO release in base-catalyzed and non-redox metal-promoted dioxygenation reactions of 3-hydroxyflavones and 3-hydroxy-4-oxoquinolines.

\subsection{Summary}

Overall, the 3-hydroxyflavone derivatives exhibit cleaner reactivity under base-catalyzed conditions, whereas 3-hydroxy-4-oxoquinoline derivatives exhibit competing formation of 1,2-dioxetane species. This suggests that 3-hydroxyflavones may be more reliable $\mathrm{CO}$ release agents under biological conditions.

\section{CO Production from 3-Hydroxyflavones via Photochemical Reactions}

Photooxygenation of flavonols is another reaction pathway that results in $\mathrm{CO}$ release. It is known that unsubstituted 3-hydroxyflavone (3-HflH) will undergo incorporation of both oxygen atoms of $\mathrm{O}_{2}$ and expulsion of $\mathrm{CO}$ in the presence of a photosensitizer, or via direct illumination using UV light (Scheme 15 (top)) [85,86]. The latter is suggested to proceed via the reaction of a tautomeric triplet state (formed via excited state intramolecular proton transfer, ESIPT) with ground state ${ }^{3} \mathrm{O}_{2}$ to give a 5-membered cyclic endoperoxide intermediate from which CO extrusion occurs [87-89]. A similar reaction pathway has been recently proposed for the photooxygenation of 4'-diethylamino-3-hydroxyflavone [90]. Notably, 3-hydroxyflavone is also known to undergo photoinduced rearrangement in the absence of $\mathrm{O}_{2}$ (Scheme 15 (bottom)) in apolar, polar aprotic and polar protic solvents, to give a 3-hydroxy-3-aryl-indane-1,2-dione product [91-94]. In some cases, the indane-1,2-diones releases $\mathrm{CO}$ to form a 3-arylphthalide (Scheme 15).

Our laboratory has recently demonstrated that divalent metal complexes of the general formula $[(\mathrm{L}) \mathrm{Zn}(3-\mathrm{Hfl})] \mathrm{ClO}_{4}$, containing a coordinated 3-hydroxyflavonolato ligand and supported by a chelating nitrogen donor ligand (L), undergo clean UV- or visible light-induced reactivity in the presence of $\mathrm{O}_{2}$ to produce one equivalent of $\mathrm{CO}$ (determined by GC head space analysis) and a metal carboxylate (depside) complex (Scheme 16) [95-99]. The reaction quantum yield (Table 1) for CO release from these complexes depends on the ligand secondary environment of the metal complex or solvent conditions, and on the divalent metal ion present. Divalent zinc 3-hydroxyflavonolato complexes of a variety of supporting chelate ligands exhibit reaction quantum yields for $\mathrm{CO}$ release that can be tuned from $\sim 0.0003$ to $0.012[95,98,99]$. Encapsulation of the $\mathrm{Zn}$ (II)-flavonolato moiety within a hydrophobic microenvironment produced the highest reaction quantum yield whereas positioning the $\mathrm{Zn}$ (II) 3-hydroxyflavonolato unit within a hydrogen bond donor pocket produced the least reactive complex. The latter may be explained in that hydrogen-bonding involving either rigid donors in the 
secondary environment, or a hydrogen bond donor solvent (e.g., $\mathrm{H}_{2} \mathrm{O}$ ), provides additional pathways for non-radiative decay thus leading to excited state quenching and a less efficient $\mathrm{CO}$ release [98]. $\mathrm{Su}$, et al. recently reported a series of zinc flavonolato complexes supported by tetradentate tripodal nitrogen donor ligands that are similar to those reported by our laboratory and release one equivalent of CO upon visible light illumination [100]. We note that Protti, et al. previously reported that the presence of $\mathrm{O}_{2}$ enhanced the photodecomposition of simple $[\mathrm{Zn}(3-\mathrm{Hfl})]^{+}$species but did not report $\mathrm{CO}$ production [101].<smiles>O=c1c(O)c(-c2ccccc2)oc2ccccc12</smiles>

3-HfIH (normal)

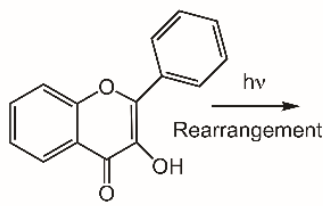<smiles>O=C(Oc1ccccc1C(=O)O)c1ccccc1</smiles><smiles>O=C1C(=O)C(O)(c2ccccc2)c2ccccc21</smiles><smiles></smiles>

3-HflH (tautomer)<smiles>O=C1OC(c2ccccc2)c2ccccc21</smiles>

Scheme 15. UV-light induced reactivity of 3-hydroxyflavone in the presence (top) and absence (bottom) of oxygen.

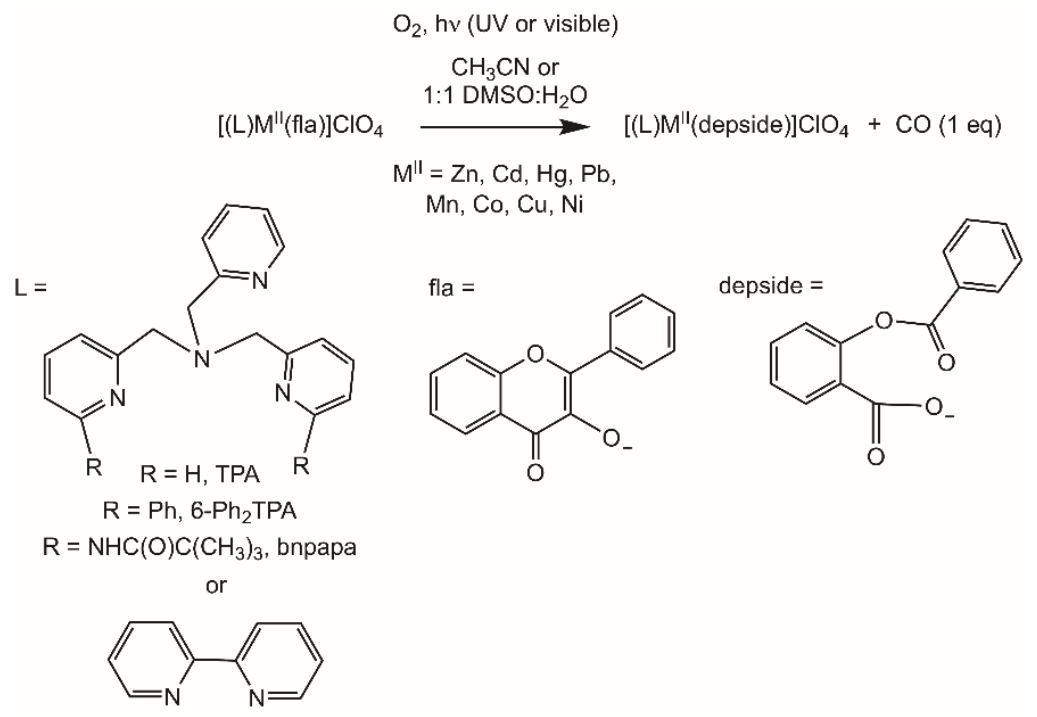

Scheme 16. UV- or visible-light-induced CO release reactivity of divalent metal flavonolato complexes.

The coordination of the 3-hydroxyflavonolato ligand to heavy closed shell metal ions ( $\mathrm{Cd}^{\mathrm{II}}<\mathrm{Hg}^{\mathrm{II}}$, and $\left.\mathrm{Pb}^{\mathrm{II}}\right)$ produced relatively high quantum yields $(>0.20)$ for $\mathrm{CO}$ release [95,96]. Conversely, coordination of the 3-hydroxyflavonolato anion to $\mathrm{Mn}(\mathrm{II}), \mathrm{Co}(\mathrm{II}), \mathrm{Ni}(\mathrm{II})$, or $\mathrm{Cu}(\mathrm{II})$ yielded complexes with low CO release reaction quantum yields (typically $\sim 0.005$ ) due to quenching of the excited state by the open-shell first row metal ion [96]. Despite the low reactivity, these complexes can serve as catalysts for the UV light-induced oxidative degradation of 3-hydroxyflavone to give O-benzoylsalicylic acid and $\mathrm{CO}$ [96]. While multiple catalysts for the thermal $\mathrm{O}_{2}$-dependent degradation of 3-hydroxyflavone with CO release have been reported $[79,102,103]$, to our knowledge this is the only light-driven catalytic reaction reported to date. We also note that a $\mathrm{Ag}(\mathrm{I})$ 3-hydroxyflavonolato complex, $\left[\mathrm{Ag}(3-\mathrm{Hfl})\left(\mathrm{PPh}_{3}\right)_{2}\right]$, was recently reported to undergo visible light-induced oxygenation to yield a depside complex [104]. No reaction quantum yield or $\mathrm{CO}$ quantification was reported for this reaction. 
Table 1. Quantum yields of UV- or visible light-induced quantitative CO-releasing reactions of divalent metal 3-hydroxyflavonolato complexes.

\begin{tabular}{|c|c|c|c|}
\hline Compound & Absorption Max. (nm) & Quantum Yield for CO Release & Reference \\
\hline$\left[\left(6-\mathrm{Ph}_{2} \mathrm{TPA}\right) \mathrm{Zn}(3-\mathrm{Hfl})\right] \mathrm{ClO}_{4}$ & 420 & $0.09(1)^{a, c}$ & {$[63,95,97]$} \\
\hline$\left[\left(6-\mathrm{Ph}_{2} \mathrm{TPA}\right) \mathrm{Zn}(3-\mathrm{Hfl})\right] \mathrm{ClO}_{4}$ & 420 & $0.012(2)^{b, c} ; 0.006(1)^{b, d}$ & [98] \\
\hline$\left[\left(6-\mathrm{Ph}_{2} \mathrm{TPA}\right) \mathrm{Cd}(3-\mathrm{Hfl})\right] \mathrm{ClO}_{4}$ & 430 & $0.28(2)^{a, c}$ & {$[95,97]$} \\
\hline$\left[\left(6-\mathrm{Ph}_{2} \mathrm{TPA}\right) \mathrm{Hg}(3-\mathrm{Hfl})\right] \mathrm{ClO}_{4}$ & 415 & $0.31(2)^{a, c}$ & {$[95,97]$} \\
\hline$\left[\left(6-\mathrm{Ph}_{2} \mathrm{TPA}\right) \mathrm{Mn}(3-\mathrm{Hfl})\right] \mathrm{ClO}_{4}$ & 415 & $0.005^{a, c}$ & [96] \\
\hline$\left[\left(6-\mathrm{Ph}_{2} \mathrm{TPA}\right) \mathrm{Co}(3-\mathrm{Hfl})\right] \mathrm{ClO}_{4}$ & 430 & $0.005^{a, c}$ & {$[96]$} \\
\hline$\left[\left(6-\mathrm{Ph}_{2} \mathrm{TPA}\right) \mathrm{Cu}(3-\mathrm{Hfl})\right] \mathrm{ClO}_{4}$ & 428 & $0.005^{a, c}$ & [96] \\
\hline$\left[\left(6-\mathrm{Ph}_{2} \mathrm{TPA}\right) \mathrm{Ni}(3-\mathrm{Hfl})\right] \mathrm{ClO}_{4}$ & 415 & $0.008^{a, c}$ & [96] \\
\hline$\left[\left(6-\mathrm{Ph}_{2} \mathrm{TPA}\right) \mathrm{Pb}(3-\mathrm{Hfl})\right] \mathrm{ClO}_{4}$ & 406 & $0.21(6)^{a, c}$ & [97] \\
\hline$[(\mathrm{TPA}) \mathrm{Zn}(3-\mathrm{Hfl})] \mathrm{ClO}_{4}$ & 415 & $0.006(1)^{b, c}$ & [98] \\
\hline$\left[(\right.$ bnpapa $) \mathrm{Zn}(3-\mathrm{Hfl}) \mathrm{ClO}_{4}$ & 401 & $0.00027(1)^{b, c}$ & [98] \\
\hline$\left\{[(\text { bpy }) \mathrm{Zn}(3-\mathrm{Hfl})]_{2}\right\}\left(\mathrm{ClO}_{4}\right)_{2}$ & 414 & $0.004(1)^{b, c}$ & [99] \\
\hline$\left[\mathrm{Ru}\left(\eta^{6}-p\right.\right.$-cymene $\left.) \mathrm{Cl}(3-\mathrm{Hfl})\right]$ & 472 & $0.001(1)^{b, c}$ & [105] \\
\hline
\end{tabular}

We have also explored the visible light-induced $\mathrm{CO}$ release reactivity of the $\left[\mathrm{Ru}\left(\eta^{6}-p\right.\right.$-cymene) $\left.\left(\mathrm{CH}_{3} \mathrm{CN}\right)(3-\mathrm{Hfl})\right] \mathrm{OTf}$ complex (Scheme 17) [105], as such complexes are promising for anticancer applications [106-108]. The combined results from product identification (ESI-MS), CO quantification, and ${ }^{18} \mathrm{O}$-isotope labeling studies upon illumination with UV $(300 \mathrm{~nm})$ and visible $(419 \mathrm{~nm})$ light in $\mathrm{CH}_{3} \mathrm{CN}$ show that oxygenation of the flavonolato ligand occurs in a dioxygenase-type manner with release of $\mathrm{CO}$. However, the amount of free $\mathrm{CO}$ generated was found to depend on the wavelength of illumination, with UV light leading to higher yield ( 0.70 eq CO). This is because the $\mathrm{Ru}(\mathrm{II})$ center acts as a trap for the released CO and UV light enables photodissociation of the metal carbonyl moiety. The quantum yield for $\mathrm{CO}$ release from $\left[\mathrm{Ru}\left(\eta^{6}-p\right.\right.$-cymene $\left.) \mathrm{Cl}(3-\mathrm{Hfl})\right]$ upon illumination at $419 \mathrm{~nm}$ is 0.001(1) which is among the lowest values measured to date for divalent metal 3-hydroxyflavonolato complexes (Table 1).

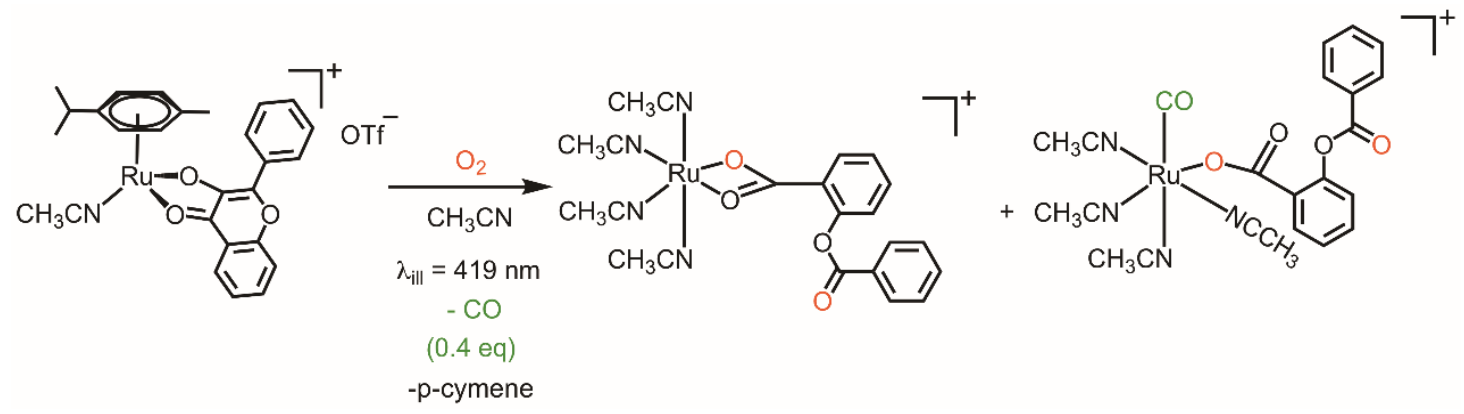

Scheme 17. Reactivity of $\mathrm{Ru}^{\mathrm{II}}$ 3-hydroxyflavonolato complex with $\mathrm{O}_{2}$ upon illuination with visible light $\left(\lambda_{\text {ill }}=419 \mathrm{~nm}\right)$ [105].

Farmer, et al. have recently synthesized and characterized a series of $\mathrm{Ru}(\mathrm{II})$ bipyridine-ligated 3-hydroxyflavonolato complexes and investigated the mechanistic details of their light-driven reactivity $[109,110]$. Illumination into distinct excitation bands at low temperature leads to products of two different reaction pathways (Scheme 18). Specifically, upon excitation at wavelengths longer than $400 \mathrm{~nm}$, the complexes undergo 1,2-addition of dioxygen, generating a 1,2-dioxetane intermediate that results in the formation of a $\mathrm{Ru}^{\mathrm{II}}$-coordinated $\alpha$-ketoacid complex. This complex is proposed to release $\mathrm{CO}$ gas to form a $\mathrm{Ru}(\mathrm{II})$ depside complex as determined by ESI-MS and deoxymyoglobin assay. Illumination of the same complex through a $310 \mathrm{~nm}$ notch pass optical filter, yields product mixtures derived from 1,3-addition of dioxygen, specifically depside coordinated to $\mathrm{Ru}(\mathrm{II})$ and $\mathrm{CO}$. The authors suggest that the observed reactivity patterns are attributed to flavonol tautomeric biradicals [110]. 


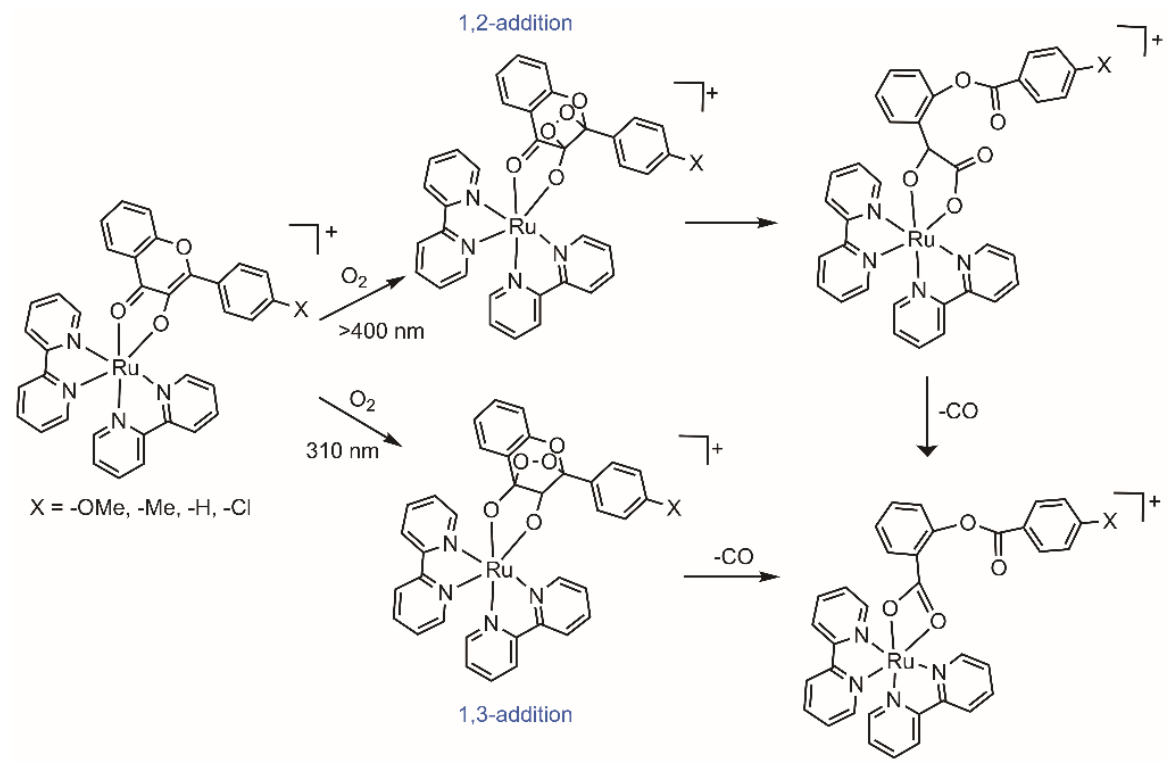

Scheme 18. Photoreactivity of $\mathrm{Ru}^{\mathrm{II}}$ 3-hydroxyflavonolato complexes with $\mathrm{O}_{2}[109,110]$.

\section{Visible Light-Induced CO Release from Extended 3-Hydroxyflavone and 3-Hydroxybenzo[g]quinolone Frameworks}

We have prepared a series of new flavonols (1-4) with an additional fused aromatic ring (Scheme 19) to shift the absorption maximum further into the visible range. [111]. Compound 1, which ionizes partially in DMSO:PBS buffer at $\mathrm{pH}=7.4$ [112], has been extensively investigated in terms of its $\mathrm{O}_{2}$-dependent $\mathrm{CO}$ release reactivity. In a range of solvents (Table 2), 1 undergoes dioxygenase-type quantitative visible light-induced $\left(\lambda_{\text {ill }}=419\right.$ or $\left.488 \mathrm{~nm}\right)$ CO release, with the reaction quantum yield $(0.006-0.010)$ depending on the solvent $[111,112]$. The product generated is an O-benzoylsalicylate derivative (5). Notably, compound 1 has been recently shown to be amenable to two-photon excitation at $800 \mathrm{~nm}$ to trigger CO release [113]. Prior to CO release, compound $\mathbf{1}$ can be visualized in cells via its green emission at $\sim 580 \mathrm{~nm}$ (Scheme 19b). This emission, which is from a tautomeric species resulting from excited state intramolecular proton transfer (ESIPT), is lost upon release of CO, thus enabling tracking of the intracellular CO release process [111,114]. Compound $\mathbf{1}$ binds weakly to bovine serum albumin $\left(K_{\mathrm{a}}=3.2 \times 10^{3} \mathrm{M}^{-1}\right)$ at the warfarin binding Site I [112]. This interaction with a protein reduces the quantum yield for $\mathrm{CO}$ release (Table 2). Compound $\mathbf{1}$ is minimally toxic in A549 $\left(\mathrm{IC}_{50}=41 \mu \mathrm{M}\right)$, HUVECs $\left(\mathrm{IC}_{50}=82 \mu \mathrm{M}\right)$, and RAW 264.7 cells (non toxic up to $\left.100 \mu \mathrm{M}\right)[111,115,116]$. Functionalized derivatives of $\mathbf{1}$ have been used to probe mitochondrial localization of CO release [115], thiol and $\mathrm{H}_{2} \mathrm{~S}$ sensing $[117,118]$ and $\mathrm{H}_{2} \mathrm{O}_{2}$ sensing [113] prior to light-triggered $\mathrm{CO}$ release.

The diethylamino-substituted 2 (Scheme 19a; Table 2) exhibits similar quantitative, $\mathrm{O}_{2}$-dependent visible light-induced $\left(\lambda_{\text {ill }}=419 \mathrm{~nm}\right)$ CO release to that found for 1 . Notably, the sulfur-substituted 3 (Scheme 19a; Table 2) exhibits a much higher quantum yield (0.426(3)) for $\mathrm{CO}$ release in $\mathrm{CH}_{3} \mathrm{CN}$ with $\lambda_{\text {ill }}>546 \mathrm{~nm}$ under $\mathrm{O}_{2}$ [111]. Compound 4 exhibits quantitative $\mathrm{O}_{2}$-dependent visible light-induced CO release under aerobic conditions $\left(\lambda_{\text {ill }}>546 \mathrm{~nm}\right)$ but also produces $0.32(7)$ equivalents of $\mathrm{CO}$ under anaerobic conditions. Both reactions of 4 lead to a mixture of products, with the anaerobic $\mathrm{CO}$ release reaction appearing to involve photoisomerization akin to that observed for 3-hydroxyflavone (Scheme 15) [92-94]. The mechanism for visible-light induced CO release in 1-4 has not been computationally examined but may involve the reactivity of a triplet phototautomer formed via ESIPT reacting with ${ }^{3} \mathrm{O}_{2}[90,114]$. 
a)<smiles>O=c1c(O)c(-c2ccccc2)oc2cc3ccccc3cc12</smiles>

1<smiles>Oc1c(-c2ccccc2)oc2cc3ccccc3cc2c1=S</smiles>

3<smiles>CCN(CC)c1ccc(-c2oc3cc4ccccc4cc3c(=O)c2O)cc1</smiles><smiles>CCN(CC)c1ccc(-c2oc3cc4ccccc4cc3c(=S)c2O)cc1</smiles>

b)

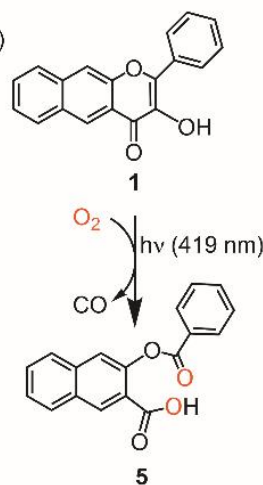

Blue channel Green channel
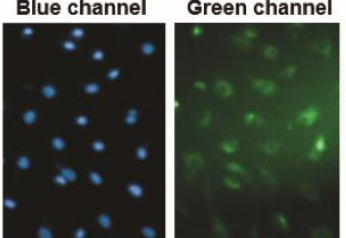

Merged

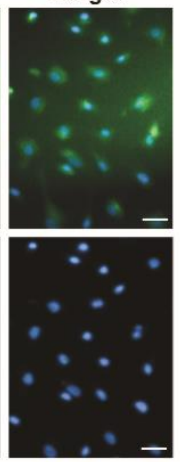

Scheme 19. (a) Extended 3-hydroxyflavone derivatives (1-4). (b, left) Visible light-induced CO release from 1. (b, right) Individual fluorescence microscopy images of HUVECs incubated with $\mathbf{1}$ for $4 \mathrm{~h}$. Row 1: Cells exposed to 1 for $4 \mathrm{~h}$. Row 2: Cells from first row illuminated (488 nm light, with a light density of 42,620 lx). Cells were also co-stained with Hoechst 33342 nuclear dye (blue) to assess cell integrity. Size of bar $=50 \mu \mathrm{m}$.

Zinc complexation of 1-4 provided the first examples of divalent metal flavonolato complexes (6-13, Scheme 20) that exhibit $\mathrm{O}_{2}$-dependent, quantitative visible light-induced solid-state $\mathrm{CO}$ release [119]. Similar to the solution reactivity of 1-3, these zinc complexes undergo reaction either in solution or in the solid state to produce $\mathrm{Zn}$ (II) O-benzoylsalicylate complexes (Scheme 20) and one equivalent of $\mathrm{CO}$ per flavonolato ligand. The quantum yields for the reactions of 6-9 are enhanced relative to the free flavonols (Table 2). Limited solubility of the $\mathrm{Zn}$ (II) bis-flavonolato complexes 10-13 in common organic solvents enabled the use of $\mathbf{1 0}$ as a visible light driven in situ CO release compound for palladium-catalyzed carbonylation [119].
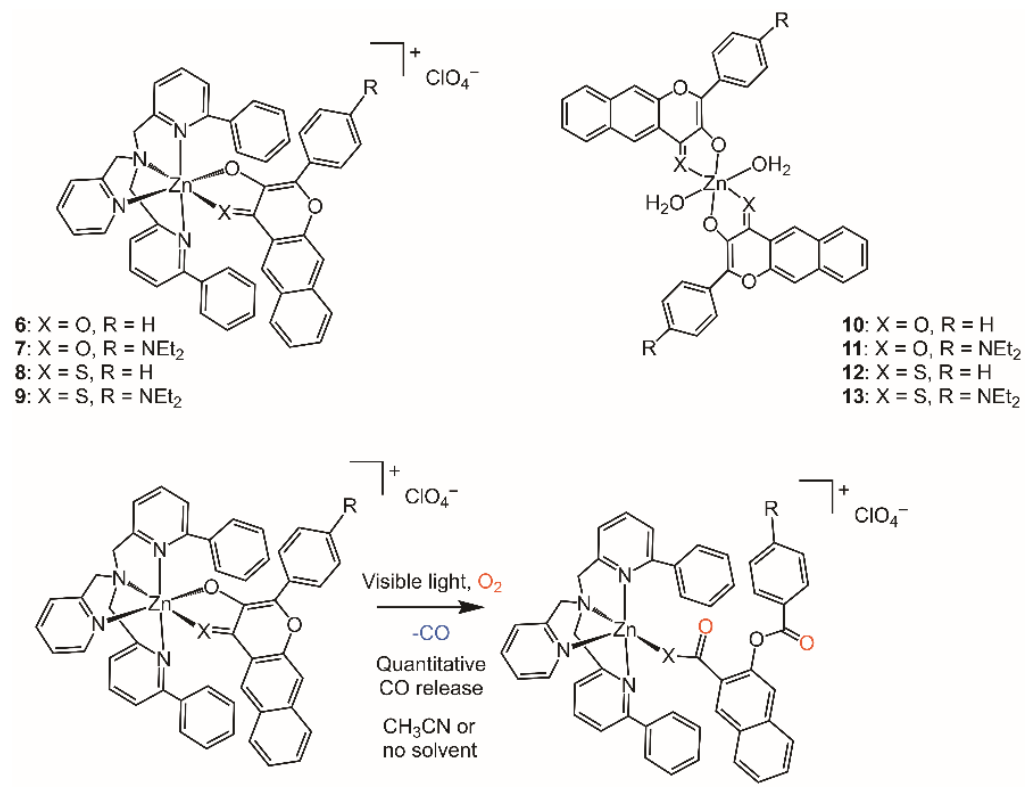

Scheme 20. Visible light-induced CO release reactivity of $\mathrm{Zn}(\mathrm{II})$ complexes of extended 3-hydroxyflavones [119]. 
Table 2. Quantum yields for photoinduced CO release from extended 3-hydroxyflavones, zinc flavonolato complexes, and 3-hydroxybenzo[g]quinolone.

\begin{tabular}{cccc}
\hline Compound & Absorption Maximum (nm) & Quantum Yield for CO Release & Reference \\
\hline $\mathbf{1}$ & $409^{b}$ & $0.007(3)^{a, c}$ & {$[111,112]$} \\
& $410^{c}$ & $0.006(3)^{a, c}$ & {$[112]$} \\
& $410^{d}$ & $0.010(3)^{a, d}$ & {$[112]$} \\
& $410^{e}$ & $0.0063(1)^{a, e}$ & {$[112]$} \\
& $410^{F}$ & $0.0006(1)^{a, f}$ & {$[112]$} \\
$\mathbf{2}$ & $442^{b}$ & $0.006(1)^{a, b}$ & {$[111]$} \\
$\mathbf{3}$ & $478^{b}$ & $0.426(3)^{a, b}$ & {$[111]$} \\
$\mathbf{4}$ & & Not determined $^{a}$ & {$[111]$} \\
$\mathbf{6}$ & $480^{b}$ & $0.651(2)^{a, b}$ & {$[119]$} \\
$\mathbf{7}$ & $54^{b}$ & $0.583(4)^{b, g}$ & {$[119]$} \\
$\mathbf{8}$ & $550^{b}$ & $0.951(4)^{b, g}$ & {$[119]$} \\
$\mathbf{9}$ & $600^{b}$ & $0.947(7)^{b, g}$ & {$[119]$} \\
$\mathbf{1 4}$ & $445^{b}$ & $0.0045(1)^{a, b}$ & {$[116]$}
\end{tabular}

${ }^{a} 419 \mathrm{~nm} ;{ }^{b} \mathrm{CH}_{3} \mathrm{CN} ;{ }^{c}$ 1:1 DMSO:TRIS; ${ }^{d} 1: 1$ DMSO:PBS; ${ }^{e} 4 \%$ DMSO:PBS + CTAB; ${ }^{f}$ BSA. (40 eq.) in 3.3\% DMSO:TRIS;

$g$ White light with $546 \mathrm{~nm}$ cut off filters.

The 3-hydroxybenzo[g]quinolone 14 (Scheme 21) was previously reported as a dye [120]. We recently demonstrated that this compound will release one equivalent of $\mathrm{CO}$ upon illumination with visible light to produce a non-emissive depside product [116]. Similar to 1, the presence of $\mathbf{1 4}$ in cells can be tracked via fluorescence prior to CO release. Notably, $\mathbf{1 4}$ has a high affinity ( $\mathrm{K}_{\mathrm{SV}} 2.9 \times 10^{6} \mathrm{M}^{-1}$ (SV = Stern-Volmer)) for bovine serum albumin (BSA) protein, binding at Site I (warfarin binding site).

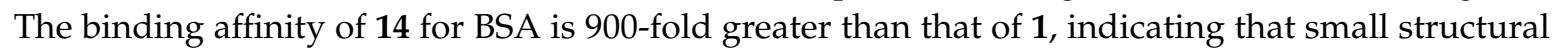
changes will dramatically influence protein interactions in these bioinspired compounds. Using the non-covalent protein:14 adduct for visible light-induced CO delivery to cells, we identified a low $\mathrm{IC}_{50}$ value $(24 \mu \mathrm{M})$ for the eradication of cancer cells (A549) and potent anti-inflammatory effects, as measured by complete suppression of LPS-induced TNF- $\alpha$ production at $80 \mathrm{nM}$ in RAW 264.7 murine macrophage cells [116]. The low $\mathrm{IC}_{50}$ value may be due in part to the known effect of serum albumin proteins in facilitating the delivery of small molecules to cancer cells via the enhanced permeability and retention effects [121]. Overall, these initial results indicate that the 3-hydroxybenzo[g]quinolone framework has significant potential as a novel CO-releasing motif for applications in biological systems.

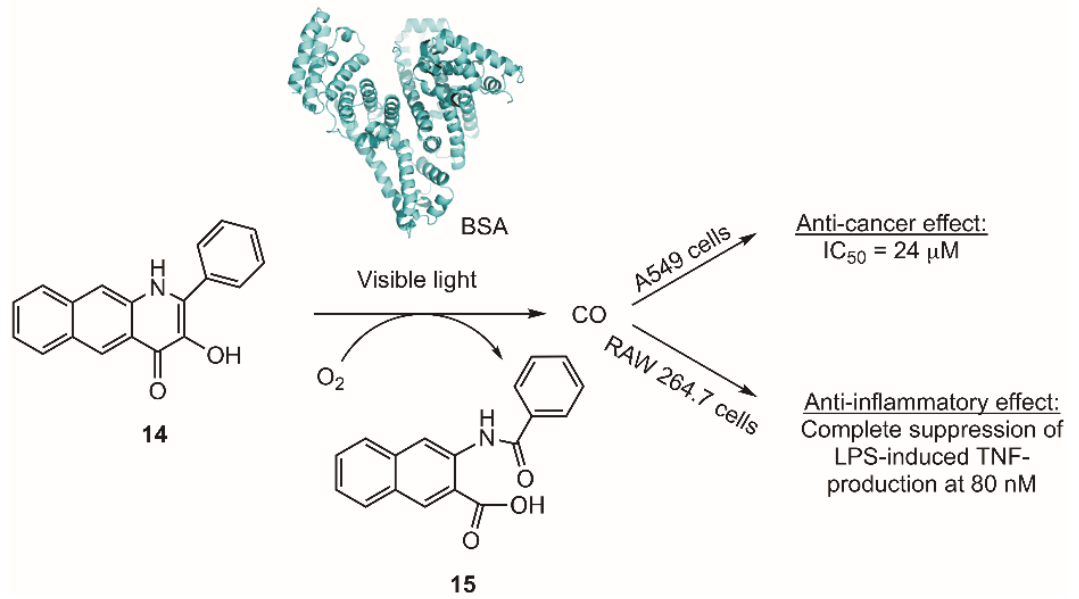

Scheme 21. CO release reactivity of $\mathbf{1 4}$ in the presence of bovine serum albumin (BSA) produces potent anti-cancer and anti-inflammatory effects [116]. 


\section{Concluding Remarks and Future Directions}

In this review we have outlined the various reported reaction pathways whereby 3-hydroxyflavone and 3-hydroxy-4-oxoquinoline compounds undergo CO release. Currently there is a strong interest in the development of carbon monoxide-releasing molecules (CORMs) that are metal free [20,122,123], especially those that can be triggered by visible light, which enables localized CO delivery. An additional desired characteristic for CORMs is a chemical framework that can be structurally modified to tune various factors including solubility, the rate of $\mathrm{CO}$ release, toxicity, and subcellular or tissue targeting [124]. The studies outlined herein demonstrate that the 3-hydroxyflavone motif will undergo $\mathrm{CO}$ release under a variety of reaction conditions, whether metal-coordinated or metal-free, and by either thermal or light-induced reaction pathways. The 3-hydroxyflavone framework is amenable to a variety of structural modifications to tune or augment chemical properties. In this regard, our lab has recently shown that an extended 3-hydroxyflavone motif can be structurally modified to enable sub-cellular targeting [115] and fluorescence-trackable small molecule sensing properties $[117,118]$ prior to CO release. An additional intriguing feature of using 3-hydroxyflavone derivatives as CORMs is the potential of these compounds to exhibit other advantageous properties such as anti-inflammatory, antioxidant and anti-cancer effects $[125,126]$ in addition to CO release. Future work in our laboratory is focused on identifying and investigating these possible dual activity effects.

Overall, the development of CORMs based on 3-hydroxyflavone and 3-hydroxy-4-oxoquinoline structural frameworks is in its early stages. Using the knowledge of the studies summarized herein we anticipate further development of CORMs based on these biologically-relevant structures. In this regard, a key next step for our laboratory will be evaluation of the CO release reactivity of a range of 3-hydroxyflavone and 3-hydroxy-4-oxoquinoline derivatives under visible light-triggered conditions. Currently, very little is known regarding the structure/reactivity relationships for light-driven reactions of these molecules. If compounds with a range of absorption properties and quantum yields can be developed, this family of compounds could enable controlled, triggered release for the delivery of specific boluses of $\mathrm{CO}$.

Funding: This work was financially supported by National Institutes of Health (R15GM124596 to L.M.B.), American Heart Association (18PRE34030099 to T.S.) and the USU Office of Research and Graduate Studies (PDRF Fellowship to T.S.).

Conflicts of Interest: The authors declare no conflict of interest.

\section{References}

1. Motterlini, R.; Foresti, R. Biological signaling by carbon monoxide and carbon monoxide-releasing molecules. Am. J. Physiol. Cell Physiol. 2017, 312, C302-C313. [CrossRef] [PubMed]

2. Motterlini, R.; Otterbein, L.E. The therapeutic potential of carbon monoxide. Nat. Rev. Drug Discov. 2010, 9, 728-743. [CrossRef] [PubMed]

3. Kim, H.-H.; Choi, S. Therapeutic aspects of carbon monoxide in cardiovascular disease. Int. J. Mol. Sci. 2018, 19, 2381. [CrossRef] [PubMed]

4. Lee, S.R.; Nilius, B.; Han, J. Gaseous Signaling Molecules in Cardiovascular Function: From Mechanism to Clinical Translation. In Reviews of Physiology, Biochemistry, and Pharmacology; Nilius, B., de Tombe, P., Gundermann, T., Jah, R., Lill, R., Peterson, O.H., Eds.; Springer International Publishing: Berlin/Heidelberg, Germany, 2018; Volume 174, pp. 81-156.

5. Otterbein, L.E.; Foresti, R.; Motterlini, R. Heme oxygeanse-1 and carbon monoxide in the heart: The balancing act between danger signaling and pro-survival. Circ. Res. 2016, 118, 1940-1959. [CrossRef] [PubMed]

6. Fredenburgh, L.E.; Merz, A.A.; Cheng, S. Haeme oxygenase signalling pathway: Implications for cardiovascular disease. Eur. Heart J. 2015, 36, 1512-1518. [CrossRef] [PubMed]

7. Szabo, C. Gasotransmitters in cancer: From pathophysiology to experimental therapy. Nat. Rev. Drug Discov. 2016, 15, 185-203. [CrossRef] [PubMed] 
8. Jin, Q.; Deng, Y.; Jia, F.; Tang, Z.; Ji, J. Gas therapy: An emerging "green" strategy for anticancer therapeutics. Adv. Therap. 2018, 1, 1800084. [CrossRef]

9. Motterlini, R. Carbon monoxide-releasing molecules (CO-RMs): Vasodilatory, anti-ischaemic and anti-inflammatory activities. Biochem. Soc. Trans. 2007, 35, 1142-1146. [CrossRef]

10. Crook, S.H.; Mann, B.E.; Meijer, A.J.H.M.; Adams, H.; Sawle, P.; Scapens, D.; Motterlini, R. $\left[\mathrm{Mo}(\mathrm{CO})_{4}\right.$ $\left.\left\{\mathrm{S}_{2} \mathrm{CNMe}\left(\mathrm{CH}_{2} \mathrm{CO}_{2} \mathrm{H}\right)\right\}\right]$, a new water-soluble CO-releasing molecule. Dalton Trans. 2011, 40, 4230-4235. [CrossRef]

11. Aki, T.; Unuma, K.; Noritake, K.; Kurahashi, H.; Funakoshi, T.; Uemura, K. Interaction of carbon monoxide-releasing ruthenium carbonyl CORM-3 with plasma fibronectin. Toxicol. In Vitro 2018, 50, 201-209. [CrossRef] [PubMed]

12. Chaves-Ferreira, M.; Albuquerque, I.S.; Matak-Vinkovic, D.; Coelho, A.C.; Carvalho, S.M.; Saraiva, L.M.; Romão, C.C.; Bernardes, G.J.L. Spontaneous $\mathrm{CO}$ release from $\mathrm{Ru}^{\mathrm{II}}(\mathrm{CO})_{2}$-protein complexes in aqueous solution, cells, and mice. Angew. Chem. Int. Ed. 2015, 54, 1172-1175. [CrossRef] [PubMed]

13. Seixas, J.D.; Santos, M.F.A.; Mukhopadhyay, A.; Coelho, A.C.; Reis, P.M.; Veiros, L.F.; Marques, A.R.; Penacho, N.; Gonçalves, A.M.; Romão, M.J.; et al. A contribution to the rational design of $\mathrm{Ru}(\mathrm{CO})_{3} \mathrm{Cl}_{2} \mathrm{~L}$ complexes for in vivo delivery of CO. Dalton Trans. 2015, 44, 5058-5075. [CrossRef] [PubMed]

14. Santos-Silva, T.; Mukhopadhyay, A.; Seixas, J.D.; Bernardes, G.J.L.; Romão, C.C.; Romão, M.J. Towards improved therapeutic CORMs: Understanding the reactivity of CORM-3 with proteins. Curr. Med. Chem. 2011, 18, 3361-3366. [CrossRef]

15. Santos-Silva, T.; Mukhopadhyay, A.; Seixas, J.D.; Bernardes, G.J.L.; Romão, C.C.; Romão, M.J. CORM-3 reactivity toward proteins: The crystal structure of $\mathrm{Ru}(\mathrm{II})$ dicarbonyl-lysozyme complex. J. Am. Chem. Soc. 2011, 133, 1192-1195. [CrossRef]

16. Wang, P.; Liu, H.; Zhao, Q.; Chen, Y.; Liu, B.; Zhang, B.; Zheng, Q. Syntheses and evaluation of drug-like properties of CO-releasing molecules containing ruthenium and group 6 metal. Eur. J. Med. Chem. 2014, 74, 199-215. [CrossRef]

17. Davidge, K.S.; Motterlini, R.; Mann, B.E.; Wilson, J.L.; Poole, R.K. Carbon monoxide in biology and microbiology: Surprising roles for the "Detroit perfume". Adv. Microb. Physiol. 2009, 56, 85-167.

18. Southam, H.M.; Smith, T.W.; Lyon, R.L.; Liao, C.; Trevitt, C.R.; Middlemiss, L.A.; Cox, F.L.; Chapman, J.A.; El-Khamisy, S.F.; Hippler, M.; et al. A thiol-reactive $\mathrm{Ru}(\mathrm{II})$ ion, not $\mathrm{CO}$ release, underlies the potent antimicrobial and cytotoxic properties of CO-releasing molecule-3. Redox Biol. 2018, 18, 114-123. [CrossRef] [PubMed]

19. Wareham, L.K.; McLean, S.; Begg, R.; Rana, N.; Ali, S.; Kendall, J.J.; Sanguinetti, G.; Mann, B.E.; Poole, R.K. The broad-spectrum antimicrobial potential of $\left[\mathrm{Mn}(\mathrm{CO})_{4}\left(\mathrm{~S}_{2} \mathrm{CNCH}_{3}\left(\mathrm{CH}_{2} \mathrm{CO}_{2} \mathrm{H}\right)\right]\right.$, a water-soluble CO-releasing molecule (CORM-401): Intracellular accumulation, transcriptomic and statistical analyses, and membrane polarization. Antioxid. Redox Signal. 2018, 28, 1286-1308. [CrossRef] [PubMed]

20. Abeyrathna, N.; Washington, K.; Bashur, K.; Liao, Y. Nonmetallic carbon monoxide releasing molecules. Org. Biomol. Chem. 2017, 15, 8692-8699. [CrossRef] [PubMed]

21. Motterlini, R.; Sawle, P.; Hammad, J.; Bains, S.; Alberto, R.; Foresti, R.; Green, C.J. CORM-A1: A new pharmacologically active carbon monoxide-releasing molecule. FASEB J. 2005, 19, 284-286. [CrossRef]

22. Ji, X.; Wang, B. Strategies toward carbon monoxide prodrugs. Acc. Chem. Res. 2018, 51, 1377-1385. [CrossRef]

23. Peng, P.; Wang, C.; Shi, Z.; Johns, V.K.; Ma, L.; Oyer, J.; Copik, A.; Igarashi, R.; Liao, Y. Visible-light activatable organic CO-releasing molecules (PhotoCORMs) that simultaneously generate fluorophores. Org. Biomol. Chem. 2013, 11, 6671-6674. [CrossRef] [PubMed]

24. Antony, L.A.P.; Slanina, T.; Sebej, P.; Solomek, T.; Klán, P. Fluorescein analogue xanthene-9-carboxylic acid: A transition-metal-free CO releasing molecule activated by green light. Org. Lett. 2013, 15, 4552-4555. [CrossRef] [PubMed]

25. Palao, E.; Slanina, T.; Muchová, L.; Solomek, T.; Vitek, L.; Klán, P. Transition-metal-free CO-releasing BODIPY derivatives activatable by visible to NIR light as promising bioactive molecules. J. Am. Chem. Soc. 2016, 138, 126-133. [CrossRef] [PubMed]

26. Sjöstrand, T. The in vitro formation of carbon monoxide in blood. Acta Physiol. Scand. 1952, 24, $314-332$. [CrossRef] [PubMed]

27. Sjöstrand, T. Endogenous formation of carbon monoxide in man under normal and pathological conditions. Scan. J. Clin. Lab. Investig. 1949, 1, 201-214. [CrossRef] 
28. Elbirt, K.K.; Bonkovksy, H.L. Heme oxygenase: Recent advances in understanding its regulation and role. Proc. Assoc. Am. Physicians 1999, 111, 438-447. [CrossRef]

29. Fetzner, S. Ring-cleaving dioxygenases with a cupin fold. Appl. Environ. Microbiol. 2012, 78, $2505-2514$. [CrossRef] [PubMed]

30. Fetzner, S.; Steiner, R.A. Cofactor-independent oxidases and oxygenases. Appl. Microbiol. Biotechnol. 2010, 86, 791-804. [CrossRef]

31. Conrad, R.; Seiler, W. Role of microorganisms in the consumption and production of atmospheric carbon monoxide by soil. Appl. Environ. Microbiol. 1980, 40, 437-445. [PubMed]

32. Patel, R.V.; Mistry, B.M.; Shinde, S.K.; Syed, R.; Singh, V.; Shin, H.S. Therapeutic potential of quercetin as a cardiovascular agent. Eur. J. Med. Chem. 2018, 155, 889-904. [CrossRef]

33. Rauf, A.; Imran, M.; Khan, I.A.; Ur-Rehman, M.; Gilani, S.A.; Mehmood, Z.; Mubarak, M.S. Anticancer potential of quercetin: A comprehensive review. Phytother. Res. 2018, 32, 2109-2130. [CrossRef]

34. Sharma, A.; Kashyap, D.; Sak, K.; Tuli, H.S.; Sharma, A.K. Therapeutic charm of quercetin and its derivatives: A review of research and patents. Pharm. Pat. Anal. 2018, 7, 15-32. [CrossRef]

35. Steiger, C.; Hermann, C.; Meinel, L. Localized delivery of carbon monoxide. Eur. J. Pharm. Biopharm. 2017, 118, 3-12. [CrossRef]

36. Fusetti, F.; Schröter, K.H.; Steiner, R.A.; van Noort, P.I.; Pijning, T.; Rozeboom, H.J.; Kalk, K.H.; Egmond, M.R.; Dijkstra, B.W. Crystal structure of the copper-containing quercetin 2,3-dioxygenase from Aspergillus japonicus. Structure 2002, 10, 259-268. [CrossRef]

37. Steiner, R.A.; Meyer-Klaucke, W.; Dijkstra, B.W. Functional analysis of the copper-dependent quercetin 2,3-dioxygenase. 2. X-ray absorption studies of native enzyme and anaerobic complexes with the substrates quercetin and myricetin. Biochemistry 2002, 41, 7963-7968. [CrossRef] [PubMed]

38. Steiner, R.A.; Kalk, K.H.; Dijkstra, B.W. Anaerobic enzyme-substrate structures provide insight into the reaction mechanism of the copper-dependent quercetin 2,3-dioxygenase. Proc. Natl. Acad. Sci. USA 2002, 99, 16625-16630. [CrossRef] [PubMed]

39. Siegbahn, P.E.M. Hybrid DFT study of the mechanism of quercetin 2,3-dioxygenase. Inorg. Chem. 2004, 43, 5944-5953. [CrossRef] [PubMed]

40. Fiorucci, S.; Golebiowski, J.; Carbol-Bass, D.; Antonczak, S. Oxygenolysis of flavonoid compounds: DFT description of the mechanism for quercetin. ChemPhysChem 2004, 5, 1726-1733. [CrossRef] [PubMed]

41. Oka, T.; Simpson, F.J.; Krishnamurty, H.G. Degradation of rutin by Aspergillus flavus. Studies on specificity, inhibition, and possible reaction mechanism of quercetinase. Can. J. Microbiol. 1972, 18, 493-508. [CrossRef]

42. Fiorucci, S.; Golebiowski, J.; Carbrol-Bass, D.; Antonczak, S. Molecular simulations bring new insights into flavonoid/quercetinase interaction modes. Proteins 2007, 67, 961-970. [CrossRef] [PubMed]

43. Barney, B.M.; Schaab, M.R.; LoBrutto, R.; Francisco, W.A. Evidence for a new metal in a known active site: Purification and characterization of an iron-containing quercetin 2,3-dioxygenase from Bacillus subtilis. Protein Expr. Purif. 2004, 35, 131-141. [CrossRef]

44. Bowater, L.; Fairhurst, S.A.; Just, V.J.; Bornemann, S. Bacillus subtilis YxaG is a novel Fe-containing quercetin 2,3-dioxygenase. FEBS Lett. 2004, 557, 45-48. [CrossRef]

45. Gopal, B.; Madan, L.L.; Betz, S.F.; Kossiakoff, A.A. The crystal structure of a quercetin 2,3-dioxygenase from Bacillus subtilis suggests modulation of enzyme activity by a change in the metal ion at the active site(s). Biochemistry 2005, 44, 193-201. [CrossRef]

46. Schaab, M.R.; Barney, B.M.; Francisco, W.A. Kinetic and spectroscopic studies on the quercetin 2,3-dioxygenase from Bacillus subtilis. Biochemistry 2006, 45, 1009-1016. [CrossRef]

47. Merkens, H.; Sielker, S.; Rose, K.; Fetzner, S. A new monocupin quercetinase of Streptomyces sp. FLA: Identification and heterologous expression of the queD gene and activity of the recombinant enzyme towards different flavonols. Arch. Microbiol. 2007, 187, 475-487. [CrossRef]

48. Merkens, H.; Kappl, R.; Jakob, R.P.; Schmid, F.X.; Fetzner, S. Quercetinase QueD of Streptomyces sp. FLA, a monocupin dioxygenase with a preference for nickel and cobalt. Biochemistry 2008, 47, 12185-12196. [CrossRef]

49. Nianios, D.; Thierbach, S.; Steimer, L.; Lulchev, P.; Klostermeier, D.; Fetzner, S. Nickel quercetinase, a "promiscuous" metalloenzyme: Metal incorporation and metal ligand substitution studies. BMC Biochem. 2015, 16, 10. [CrossRef] [PubMed] 
50. Jeoung, J.H.; Nianios, D.; Fetzner, S.; Dobbek, H. Quercetin 2,4-dioxygenase activates dioxygen in a side-on $\mathrm{O}_{2}$-Ni Complex. Angew. Chem. Int. Ed. Engl. 2016, 55, 3281-3284. [CrossRef] [PubMed]

51. Li, H.; Wang, X.; Tian, G.; Liu, Y. Insights into the dioxygen activation and catalytic mechanism of the nickel-containing quercetinase. Catal. Sci. Technol. 2018, 8, 2340-2351. [CrossRef]

52. Wang, W.-J.; Wei, W.-J.; Liao, R.-Z. Deciphering the chemoselectivity of nickel-dependent quercetin 2,4-dioxygenase. Phys. Chem. Chem. Phys. 2018, 20, 15784-15794. [CrossRef] [PubMed]

53. Kumar, M.R.; Zapata, A.; Ramirez, A.J.; Bowen, S.K.; Francisco, W.A.; Farmer, P.J. Nitrosyl hydride (HNO) replaces dioxygen in nitroxygenase activity of manganese quercetin dioxygenase. Proc. Natl. Acad. Sci. USA 2011, 108, 18926-18931. [CrossRef]

54. Shafirovich, V.; Lymar, S.V. Spin-forbidden deprotonation of aqueous nitroxyl (HNO). J. Am. Chem. Soc. 2003, 125, 6547-6552. [CrossRef] [PubMed]

55. Wojdyla, Z.; Borowski, T. DFT study of the mechanism of manganese quercetin 2,3-dioxygenase: Quest for origins of enzyme unique nitroxygenase activity and regioselectivity. J. Biol. Inorg. Chem. 2016, 21, 475-489. [CrossRef]

56. Kaizer, J.; Balogh-Hergovich, E.; Czaun, M.; Csay, T.; Speier, G. Redox and nonredox metal assisted model systems with relevance to flavonol and 3-hydroxyquinolin-4(1H)-one 2,4-dioxygenase. Coord. Chem. Rev. 2006, 250, 2222-2233. [CrossRef]

57. Pap, J.S.; Kaizer, J.; Speier, G. Model systems for the CO-releasing flavonol 2,4-dioxygenase enzyme. Coord. Chem. Rev. 2010, 254, 781-793. [CrossRef]

58. Kaizer, J.; Pap, J.S.; Speier, G. Copper Dioxygenases. In Copper-Oxygen Chemistry; Karlin, K.D., Itoh, S., Eds.; John Wiley \& Sons, Inc.: Hoboken, NJ, USA, 2011; pp. 23-52.

59. Barhács, L.; Kaizer, J.; Pap, J.; Speier, G. Kinetics and mechanism of the stoichiometric oxygenation of $\left[\mathrm{Cu}^{\mathrm{II}}(\mathrm{fla})(\mathrm{idpa}) \mathrm{ClO}_{4}\right.$ [fla = flavonolate, idpa = 3,3'-imino-bis $(N, N$-dimethylpropylamine $\left.)\right]$ and the $\left[\mathrm{Cu}^{\mathrm{II}}\right.$ (fla)(idpa]ClO${ }_{4}$-catalyzed oxygenation of flavonol. Inorg. Chim. Acta 2001, 320, 83-91. [CrossRef]

60. Balogh-Hergovich, É.; Kaizer, J.; Speier, G. Carboxylate-enhanced reactivity in the oxygenation of copper flavonolate complexes. J. Mol. Catal. A Chem. 2003, 206, 83-87. [CrossRef]

61. Balogh-Hergovich, É.; Kaizer, J.; Pap, J.; Speier, G.; Huttner, G.; Zsolnai, L. Copper-mediated oxygenolysis of flavonols via endoperoxide and dioxetan intermediates. Synthesis and oxygenation of $\left[\mathrm{Cu}^{\mathrm{II}} \text { (phen) }\right)_{2}(\mathrm{fla}) \mathrm{ClO}_{4}$ and $\left[\mathrm{Cu}^{\mathrm{II}}(\mathrm{L})(\mathrm{fla})_{2}\right][\mathrm{flaH}=$ flavonol; $\mathrm{L}=1,10$-phenanthroline (phen), 2,2'-bipyridine (bpy), N,N,N',N'-tetramethylethylenediamine (tmeda)] complexes. Eur. J. Inorg. Chem. 2002, 2002, 2287-2295.

62. Hiatt, R. Organic Peroxides; Swern, D., Ed.; Wiley Interscience: New York, NY, USA, 1971; Volume III, p. 70.

63. Grubel, K.; Rudzka, K.; Arif, A.M.; Klotz, K.L.; Halfen, J.A.; Berreau, L.M. Synthesis, characterization, and ligand exchange reactivity of a series of first row divalent metal 3-hydroxyflavonolate complexes. Inorg. Chem. 2010, 49, 82-96. [CrossRef]

64. Sun, Y.-J.; Huang, Q.-Q.; Tano, T.; Itoh, S. Flavonolate complexes of $\mathrm{M}^{\mathrm{II}}(\mathrm{M}=\mathrm{Mn}, \mathrm{Fe}, \mathrm{Co}, \mathrm{Ni}, \mathrm{Cu}$, and $\mathrm{Zn})$. Structural and functional models for the ES (enzyme-substrate) complex of quercetin 2,3-dioxygenase. Inorg. Chem. 2013, 52, 10936-10948. [CrossRef] [PubMed]

65. Matuz, A.; Giorgi, M.; Speier, G.; Kaizer, J. Structural and functional comparison of manganese-, iron-, cobalt-, nickel-, and copper-containing biomimic quercetinase models. Polyhedron 2013, 63, 41-49. [CrossRef]

66. Sun, Y.-J.; Huang, Q.-Q.; Zhang, J.-J. Series of structural and functional models for the ES (enzyme-substrate) complex of the Co(II)-containing quercetin 2,3-dioxygenase. Inorg. Chem. 2014, 53, 2932-2942. [CrossRef] [PubMed]

67. Sun, Y.-J.; Huang, Q.-Q.; Zhang, J.-J. A series of Ni ${ }^{\mathrm{II}}$-flavonolate complexes as structural and functional ES (enzyme-substrate) models of the $\mathrm{Ni}^{\mathrm{II}}$-containing quercetin 2,3-dioxygenase. Dalton Trans. 2014, 43, 6480-6489. [CrossRef]

68. Sun, Y.-J.; Huang, Q.-Q.; Zhang, J.-J. Set of Fe(II)-3-hydroxyflavonolate enzyme-substrate model complexes of atypically coordinated mononuclear non-heme Fe(II)-dependent quercetin 2,4-dioxygenase. ACS Omega 2017, 2, 5850-5860. [CrossRef]

69. Kaizer, J.; Baráth, G.; Pap, J.; Speier, G.; Giorgi, M.; Réglier, M. Manganese and iron flavonolates as flavonol 2,4-dioxygenase mimics. Chem. Commun. 2007, 5235-5237. [CrossRef] [PubMed]

70. Balogh-Hergovich, É; Kaizer, J.; Speier, G.; Argay, G.; Párkányi, L. Kinetic studies on the copper(II)-mediated oxygenolysis of the flavonolate ligand. Crystal structures of $\left[\mathrm{Cu}(\mathrm{fla})_{2}\right](\mathrm{fla}=$ flavonolate $)$ and $\left[\mathrm{Cu}(\mathrm{O}-\mathrm{bs})_{2}(\mathrm{py})_{3}\right]$ (O-bs = O-benzoylsalicylate). J. Chem. Soc. Dalton Trans. 1999, 3847-3854. [CrossRef] 
71. Balogh-Hergovich, É.; Kaizer, J.; Speier, G.; Fülöp, V.; Párkányi, L. Quercetin 2,3-dioxygenase mimicking ring cleavage of the flavonolate ligand assisted by copper. Synthesis and characterization of copper(I) complexes $\left[\mathrm{Cu}\left(\mathrm{PPh}_{3}\right)_{2}\right.$ (fla) $]($ fla $=$ flavonolate $)$ and $\left[\mathrm{Cu}\left(\mathrm{PPh}_{3}\right)_{2}(\mathrm{O}-\mathrm{bs})\right](\mathrm{O}-\mathrm{bs}=\mathrm{O}$-benzoylsalicylate $)$. Inorg. Chem. 1999, 38, 3787-3795. [CrossRef]

72. Baráth, G.; Kaizer, J.; Speier, G.; Párkányi, L.; Kuzmann, E.; Vértes, A. One metal-two pathways to the carboxylate-enhanced, iron-containing quercetinase mimics. Chem. Commun. 2009, 3630-3632. [CrossRef] [PubMed]

73. Frerichs-Deeken, U.; Ranguelova, K.; Kappl, R.; Hüttermann, J.; Fetzner, S. Dioxygenases without requirement for cofactors and their chemical model reaction: Compulsory order ternary complex mechanism of 1H-3-hydroxy-4-oxoquinaldine 2,4-dioxygenase involving general base catalysis by histidine 251 and single-electron oxidation of the substrate dianion. Biochemistry 2004, 43, 14485-14499.

74. Steiner, R.A.; Janssen, H.J.; Roversi, P.; Oakley, A.J.; Fetzner, S. Structural basis for cofactor-independent dioxygenation of N-heteroaromatic compounds at the alpha/beta-hydrolase fold. Proc. Natl. Acad. Sci. USA 2010, 107, 657-662. [CrossRef]

75. Thierbach, S.; Bui, N.; Zapp, J.; Chhabra, S.R.; Kappl, R.; Fetzner, S. Substrate-assisted $\mathrm{O}_{2}$ activation in a cofactor-independent dioxygenase. Chem. Biol. 2014, 21, 217-225. [CrossRef]

76. Hernández-Ortega, A.; Quesne, M.G.; Bui, S.; Heyes, D.J.; Steiner, R.A.; Scrutton, N.S.; de Visser, S.P. Catalytic mechanism of cofactor-free dioxygenases and how they circumvent spin-forbidden oxygenation of their substrates. J. Am. Chem. Soc. 2015, 137, 7474-7487. [CrossRef] [PubMed]

77. Bui, S.; Steiner, R.A. New insight into cofactor-free oxygenation from combined experimental and computational approaches. Curr. Opin. Struct. Biol. 2016, 41, 109-118. [CrossRef]

78. Czaun, M.; Speier, G.; Párkányi, L. Facile copper-mediated activation of the N-H bond and the oxidative cleavage of the C2-C3 bond in 1H-2-phenyl-3-hydroxy-4-oxoquinoline. Chem. Commun. 2004, 1004-1005. [CrossRef] [PubMed]

79. Pap, J.S.; Matuz, A.; Baráth, G.; Kripli, B.; Giorgi, M.; Speier, G.; Kaizer, J. Bio-inspired flavonol and quinolone dioxygenation by a non-heme iron catalyst modeling the action of flavonol and 3-hydroxy-4(1H) — quinolone 2,4-dioxygenases. J. Inorg. Biochem. 2012, 108, 15-21. [CrossRef] [PubMed]

80. Nishinaga, A.; Tojo, T.; Tomita, H.; Matsuura, T. Base-catalysed oxygenolysis of 3-hydroxyflavones. J. Chem. Soc. Perkin Trans. 1 1979, 2511-2516. [CrossRef]

81. Barhács, L.; Kaizer, J.; Speier, G. Kinetics and mechanism of the oxygenation of potassium flavonolate. Evidence for an electron transfer mechanism. J. Org. Chem. 2000, 65, 3449-3452. [CrossRef]

82. Balogh-Hergovich, É.; Speier, G. Kinetics and mechanism of the base-catalyzed oxygenation of flavonol in DMSO- $\mathrm{H}_{2} \mathrm{O}$ solution. J. Org. Chem. 2001, 66, 7974-7978. [CrossRef]

83. Han, X.; Kumar, M.R.; Farmer, P.J. Nitroxygenation of quercetin by HNO. Tetrahedron Lett. 2016, 57, $399-402$. [CrossRef]

84. Czaun, M.; Speier, G. The base-catalyzed oxygenation of quinolone derivatives. Tetrahedron Lett. 2002, 43, 5961-5963. [CrossRef]

85. Matsuura, T.; Matsushima, H.; Nakashima, R. Photoinduced reactions-XXXVI: Photosensitized oxygenation of 3-hydroxyflavones as a nonenzymatic model for quercetinase. Tetrahedron 1970, 26, 435-443. [CrossRef]

86. Studer, S.L.; Brewer, W.E.; Martinez, M.L.; Chou, P.T. Time-resolved study of the photooxygenation of 3-hydroxyflavone. J. Am. Chem. Soc. 1989, 111, 7643-7644. [CrossRef]

87. Brewer, W.E.; Studer, S.L.; Standiford, M.; Chou, P.T. Dynamics of the triplet state and the reverse proton transfer of 3-hydroxyflavone. J. Phys. Chem. 1989, 93, 6088-6094. [CrossRef]

88. Martinez, M.L.; Studer, S.L.; Chou, P.T. Direct evidence of the triplet-state origin of the slow reverse proton transfer reaction of 3-hydroxyflavone. J. Am. Chem. Soc. 1990, 112, 2427-2429. [CrossRef]

89. Sisa, M.; Bonnet, S.L.; Ferreira, D.; Van der Westhuizen, J.H. Photochemistry of flavonoids. Molecules 2010, 15, 5196-5245. [CrossRef] [PubMed]

90. Szakács, Z.; Bojtár, M.; Drahos, L.; Hessz, D.; Kállay, M.; Vidóczy, T.; Bitter, I.; Kubinyi, M. The kinetics and mechanism of photooxygenation of 4'-diethylamino-3-hydroxyflavone. Photochem. Photobiol. Sci. 2016, 15, 219-227. [CrossRef] [PubMed]

91. Szakács, Z.; Kállay, M.; Kubinyi, M. Theoretical study on the photooxygenation and photorearrangement reactions of 3-hydroxyflavone. RSC Adv. 2017, 7, 32185-32192. [CrossRef] 
92. Matsuura, T.; Takemoto, T.; Nakashima, R. Photoinduced reactions. LII. Photorearragement of 3-hydroxyflavones. Tetrahedron 1971, 12, 1539-1540. [CrossRef]

93. Matsuura, T.; Takemoto, T.; Nakashima, R. Photoinduced reactions-LXXI: Photorearragement of 3-hydroxyflavones to 3-aryl-3-hydroxy-1,2-indandiones. Tetrahedron 1973, 29, 3337-3340. [CrossRef]

94. Yokoe, I.; Higuchi, K.; Shirataki, Y.; Komatsu, M. Photochemistry of flavonoids. III. Photorearrangement of flavonols. Chem. Pharm. Bull. 1981, 29, 894-898. [CrossRef]

95. Grubel, K.; Laughlin, B.J.; Maltais, T.R.; Smith, R.C.; Arif, A.M.; Berreau, L.M. Photochemically-induced dioxygenase-type CO-release reactivity of group 12 metal flavonolate complexes. Chem. Commun. 2011, 47, 10431-10433. [CrossRef] [PubMed]

96. Grubel, K.; Marts, A.R.; Greer, S.M.; Tierney, D.L.; Allpress, C.J.; Anderson, S.N.; Laughlin, B.J.; Smith, R.C.; Arif, A.M.; Berreau, L.M. Photoinitiated dioxygenase-type reactivity of open-shell $3 \mathrm{~d}$ divalent metal flavonolato complexes. Eur. J. Inorg. Chem. 2012, 2012, 4750-4757. [CrossRef]

97. Grubel, K.; Saraf, S.L.; Anderson, S.N.; Laughlin, B.J.; Smith, R.C.; Arif, A.M.; Berreau, L.M. Synthesis, characterization, and photoinduced $\mathrm{CO}$-release reactivity of a $\mathrm{Pb}$ (II) flavonolate complex: Comparisons to Group 12 analogs. Inorg. Chim. Acta 2013, 407, 91-97. [CrossRef]

98. Anderson, S.N.; Noble, M.; Grubel, K.; Marshall, B.; Arif, A.M.; Berreau, L.M. Influence of supporting ligand microenvironment on the aqueous stability and visible light-induced CO-release reactivity of zinc flavonolato species. J. Coord. Chem. 2014, 67, 4061-4075. [CrossRef]

99. Sorenson, S.; Popova, M.; Arif, A.M.; Berreau, L.M. A bipyridine-ligated zinc(II) complex with bridging flavonolate ligation: Synthesis, characterization and visible-light-induced CO release reactivity. Acta Cryst. 2017, C73, 703-709. [CrossRef]

100. Su, Y.; Yang, W.; Yang, X.; Zhang, R.; Zhao, J. Visible light-induced CO-release reactivity of a series of $\mathrm{Zn}^{\mathrm{II}}$-flavonolate complexes. Aust. J. Chem. 2018, 71, 549-558. [CrossRef]

101. Protti, S.; Mezzetti, A.; Lapouge, C.; Cornard, J.-P. Photochemistry of metal complexes of 3-hydroxyflavone: Towards a better understanding of the influence of solar light on the metal-soil organic matter interactions. Photochem. Photobiol. Sci. 2008, 7, 109-119. [CrossRef]

102. Sun, Y.-J.; Huang, Q.-Q.; Li, P.; Zhang, J.-J. Catalytic dioxygenation of flavonol by $\mathrm{M}^{\mathrm{II}}$-complexes (M = Mn, $\mathrm{Fe}, \mathrm{Co}, \mathrm{Ni}, \mathrm{Cu}$, and $\mathrm{Zn}$ )-Mimicking the $\mathrm{M}^{\mathrm{II}}$-substituted quercetin 2,3-dioxygenase. Dalton Trans. 2015, 44, 13926-13938. [CrossRef]

103. Sun, Y.-J.; Li, P.; Huang, Q.-Q.; Zhang, J.-J.; Itoh, S. Dioxygenation of flavonol catalyzed by copper(II) complexes supported by carboxylate-containing ligands: Structural and functional models of quercetin 2,4-dioxygenase. Eur. J. Inorg. Chem. 2017, 2017, 1845-1854. [CrossRef]

104. Vogler, A.; Hischa, B. Synthesis, crystal structure, photoluminescence and photochemistry of bis(triphenylphosphine)siliver(I) flavonolate. Z. Naturforsch. B 2018, 74. [CrossRef]

105. Saraf, S.L.; Fish, T.J.; Benninghoff, A.D.; Buelt, A.A.; Smith, R.C.; Berreau, L.M. Photochemical reactivity of $\mathrm{Ru}^{\mathrm{II}}\left(\eta^{6}\right.$-p-cymene) flavonolato compounds. Organometallics 2014, 33, 6341-6351. [CrossRef]

106. Kurzwernhart, A.; Kandioller, W.; Bartel, C.; Bächler, S.; Trondl, R.; Mühlgassner, G.; Jakupec, M.A.; Arion, V.B.; Marko, D.; Keppler, B.K.; et al. Targeting the DNA-topoisomerase complex in a double-strike approach with a topoisomerase inhibiting moiety and covalent DNA binder. Chem. Commun. 2012, 48, 4839-4841. [CrossRef]

107. Kurzwernhart, A.; Kandioller, W.; Bächler, S.; Bartel, C.; Martic, S.; Buczkowska, M.; Mühlgassner, G.; Jakupec, M.A.; Kraatz, H.-B.; Bednarski, P.J.; et al. Structure-activity relationships of targeted $\mathrm{Ru}{ }^{\mathrm{II}}\left(\eta^{6}-p\right.$-cymene) anticancer complexes with flavonol-derived ligands. J. Med. Chem. 2012, 55, 10512-10522. [CrossRef]

108. Kurzwernhart, A.; Kandioller, W.; Enyedy, É.A.; Novak, M.; Jakupec, M.A.; Keppler, B.K.; Hartinger, C.G. 3-hydroxyflavones vs. 3-hydroxyquinolinones: Structure-activity relationships and stability studies on $\mathrm{Ru}$ (arene) anticancer complexes with biologically active ligands. Dalton Trans. 2013, 42, 6193-6202. [CrossRef]

109. Han, X.; Klausmeyer, K.K.; Farmer, P.J. Characterization of the initial intermediate formed during photoinduced oxygenation of the ruthenium(II) bis(bipyridyl)flavonolate complex. Inorg. Chem. 2016, 55, 7320-7322. [CrossRef] [PubMed] 
110. Han, X.; Kumar, M.R.; Hoogerbrugge, A.; Klausmeyer, K.K.; Ghimire, M.M.; Harris, L.M.; Omary, M.A.; Farmer, P.J. Mechanistic investigations of photoinduced oxygenation of Ru(II) bis-bipyridyl flavonolate complexes. Inorg. Chem. 2018, 57, 2416-2424. [CrossRef]

111. Anderson, S.N.; Richards, J.M.; Esquer, H.J.; Benninghoff, A.D.; Arif, A.M.; Berreau, L.M. A Structurally-tunable 3-hydroxyflavone motif for visible light-induced carbon monoxide-releasing molecules (CORMs). ChemistryOpen 2015, 4, 590-594. [CrossRef]

112. Popova, M.; Soboleva, T.; Arif, A.M.; Berreau, L.M. Properties of a flavonol-based photoCORM in aqueous buffered solutions: Influence of metal ions, surfactants and proteins on visible light-induced CO release. RSC Adv. 2017, 7, 21997-22007. [CrossRef]

113. Li, Y.; Shu, Y.; Liang, M.; Xie, X.; Jiao, X.; Wang, X.; Tang, B. A two-photon $\mathrm{H}_{2} \mathrm{O}_{2}$-activated CO photoreleaser. Angew. Chem. Int. Ed. Engl. 2018, 57, 12415-12419. [CrossRef] [PubMed]

114. Dick, B.; Ernsting, N.P. Excited-state intramolecular proton transfer in 3-hydroflavone isolated in solid argon: Fluorescence and fluorescence-excitation spectra and tautomer fluorescence rise time. J. Phys. Chem. 1987, 91, 4261-4265. [CrossRef]

115. Soboleva, T.; Esquer, H.J.; Anderson, S.N.; Berreau, L.M.; Benninghoff, A.D. Mitochondrial-localized versus cytosolic intracellular CO-releasing organic photoCORMs: Evaluation of CO effects using bioenergetics. ACS Chem. Biol. 2018, 13, 2220-2228. [CrossRef]

116. Popova, M.; Soboleva, T.; Ayad, S.; Benninghoff, A.D.; Berreau, L.M. Visible-light-activated quinolone carbon-monoxide-releasing molecule: Prodrug and albumin-assisted delivery enables anticancer and potent anti-inflammatory effects. J. Am. Chem. Soc. 2018, 140, 9721-9729. [CrossRef]

117. Soboleva, T.; Esquer, H.J.; Benninghoff, A.D.; Berreau, L.M. Sense and release: A thiol-responsible flavonol-based photonically driven carbon monoxide-releasing molecule that operates via a multiple-input AND logic gate. J. Am. Chem. Soc. 2017, 139, 9435-9438. [CrossRef]

118. Soboleva, T.; Benninghoff, A.D.; Berreau, L.M. An $\mathrm{H}_{2} \mathrm{~S}$-sensing/CO-releasing flavonol that operates via logic gates. ChemPlusChem 2017, 82, 1408-1412. [CrossRef] [PubMed]

119. Anderson, S.N.; Larson, M.T.; Berreau, L.M. Solution or solid-It doesn't matter: Visible light-induced CO release reactivity of zinc flavonolato complexes. Dalton Trans. 2016, 45, 14570-14580. [CrossRef] [PubMed]

120. Bilokin, M.D.; Shvadchak, V.V.; Yushchenko, D.A.; Klymchenko, A.S.; Duportail, G.; Mely, Y.; Pivovarenko, V.G. 3-hydroxybenzo[g]quinolones: Dyes with red-shifted absorption and highly resolved dual emission. Tetrahedron Lett. 2009, 50, 4714-4719. [CrossRef]

121. Sleep, D. Albumin and its application in drug delivery. Expert Opin. Drug Deliv. 2015, 12, 793-812. [CrossRef]

122. Hopper, C. Keto Acids in Carbon Monoxide Therapeutics, 2nd ed.; Independently published via Amazon: Seattle, WA, USA, 2018.

123. Slanina, T.; Sebej, P. Visible-light-activated photoCORMs: Rational design of CO-releasing organic molecules absorbing in the tissue-transparent window. Photochem. Photobiol. Sci. 2018, 17, 692-710. [CrossRef]

124. Ramão, C.C.; Blättler, W.A.; Seixas, J.D.; Bernardes, G.J.L. Developing drug molecules for therapy with carbon monoxide. Chem. Soc. Rev. 2012, 41, 3571-3583. [CrossRef] [PubMed]

125. Panche, A.N.; Diwan, A.D.; Chandra, S.R. Flavonoids: An overview. J. Nutr. Sci. 2016, 5, e47. [CrossRef] [PubMed]

126. Butun, B.; Topcu, G.; Ozturk, T. Recent advances on 3-hydroxyflavone derivatives: Structures and properties. Mini Rev. Med. Chem. 2018, 18, 98-103. [CrossRef] [PubMed]

(C) 2019 by the authors. Licensee MDPI, Basel, Switzerland. This article is an open access article distributed under the terms and conditions of the Creative Commons Attribution (CC BY) license (http:/ / creativecommons.org/licenses/by/4.0/). 